\title{
НАХОДКИ ИСКОПАЕМЫХ ОСТАТКОВ ДРЕВНИХ РАСТЕНИЙ НА СЕВЕРО-ЗАПАДЕ РУССКОЙ ПЛАТФОРМЫ С.М. Снигиревский' ${ }^{1}$ Н.С. Снигиревская ${ }^{2}$
}

${ }^{1}$ Санкт-Петербургский Государственный университет;

${ }^{2}$ Ботанический институт им. В.Л. Комарова РАН, Санкт-Петербург, Россия

Эл.noчma: s.snigirevskiy@spbu.ru; s.snig@mail.ru

Статья поступила в редакциию 13.12.2015; принята к печати 29.02.2015

Впервые приводится обзор находок ископаемых остатков растений в осадочных отложениях, развитых на Северо-Западе Русской платформы. Подчеркивается большое разнообразие остатков древних растений в отложениях венда, кембрия, ордовика, девона, карбона и в четвертичных образованиях в окрестностях Санкт-Петербурга, являющегося колыбелью отечественной палеонтологии. Указываются основные местонахождения остатков древних растений, обсуждается важность ископаемых растений для понимания геологической истории развития региона. Работа является обзорной и предназначена для широкого круга читателей, интересующихся палеонтологией и историей развития органического мира Земли, а также для специалистов, ориентированных на изучение естественной истории Северо-западного региона России.

Ключевые слова: ископаемые остатки растений, венд, кембрий, ордовик, девон, карбон, четвертичная система, Северо-Запад России.

\section{FOSSIL PLANTS IN THE NORTHWEST PART OF RUSSIAN PLATFORM S.M. Snigirevsky ${ }^{1}$, N.S. Snigirevskaya ${ }^{2}$ \\ ${ }^{1}$ Saint-Petersburg State University; ${ }^{2}$ V.L. Komarov Botanical Institute, Saint Petersburg, Russia E-mail: s.snigirevskiy@spbu.ru; s.snig@mail.ru}

The findings of plant fossils in the sediments of the northwest part of Russian Platform are reviewed. It is emphasized that quite a large variety of plant fossils related to Vendian, Cambrian, Ordovician, Devonian, Carboniferous, and Quaternary periods have been found around Saint Petersburg, the "cradle" of Russian paleontology. The main occurrences of ancient plant remains are characterized and the significance of plant fossils for understanding the geological past of the region in question is exposed. The paper is addressed to all who are concerned with paleontology as well as to specialists in the natural history of the northwest of Russia.

Keywords: plant fossils, Vendian, Cambrian, Ordovician, Devonian, Carboniferous, Quaternary, Northwest of Russia.

Санкт-Петербург - колыбель отечественной геологии и палеонтологии. Именно в его окрестностях проведены первые палеонтологические исследования в России: по берегам речек Пулковка (там, где сейчас расположен аэропорт Пулково), Ижора, Славянка, Поповка, а также в более удаленных частях Санкт-Петербургской губернии - на Волхове, Мсте, Луге и их притоках, и далее в стороны от северной столицы, на территории нынешних Новгородской, Псковской и Вологодской областей. В 1854 г. действительный статский советник Эдуард Иванович Эйхвальд (1795-1876, рис. 1) опубликовал огромный сводный труд, названный им «Палеонтология России» [30]. Именно эта работа явилась начальным пунктом, от которого можно отсчитывать историю отечественной палеонтологии. Мы здесь не упоминаем иных многочисленных, достойнейших ученых первой половины XIX в., внесших большой вклад в развитие палеонтологии в России: их работы были посвящены в основном лишь некоторым частным вопросам и не охватывали, как многотомный труд Э.И. Эйхвальда, всего разнообразия органического мира геологического прошлого на территории огромной страны.

У большинства слово «палеонтология» ассоциируется, как правило, с изучением представителей царства животных. На самом деле, одной из ее важных отраслей является палеоботаника - наука о растительном мире геологического прошлого. Именно ра-

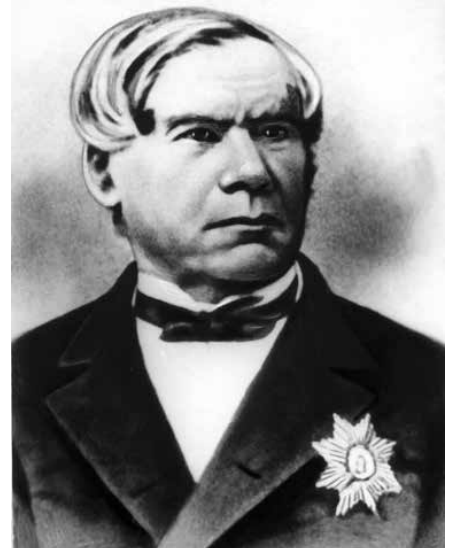

Рис. 1. Эдуард Иванович Эйхвальд (1795-1876)

стения всегда определяли и определяют облик природных сообществ, и именно растительный материал служит основой пищевых цепей в природе. Без знания особенностей развития растительности в геологическом прошлом невозможно судить о том, какие ландшафты существовали на той или иной территории, какие растительные сообщества сменяли друг друга в течение многих миллионов лет...

Целью этой статьи является обобщение имеющихся разрозненных сведений о том, какие растения обитали в геологическом прошлом на территории нынеш- 


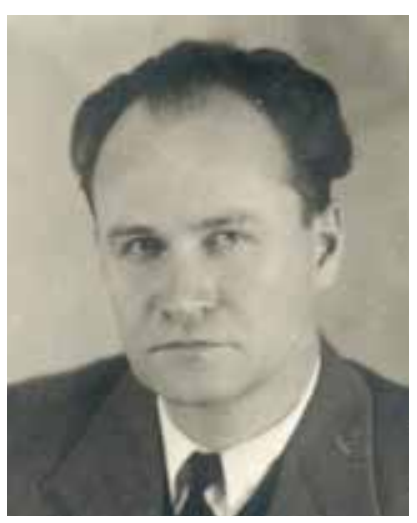

Рис. 2. Борис Сергеевич Соколов (1914-2013).

Фотография из архива кафедры осадочной геологии СПбГУ

него северо-запада европейской части России - в пределах Балтийского щита, в Ленинградской, Новгородской, на западе Архангельской и Вологодской областей. Осадочные горные породы, развитые здесь, традиционно не считались богатыми ископаемыми остатками растений, разве что за исключением четвертичных образований [23].

Палеоботанические свидетельства будут рассмотрены в хронологическом порядке - от наиболее древних к молодым. Возрастные пределы для границ эонов, эр, периодов и разделов приводятся по Стратиграфическому кодексу России [2]. При уяснении палеогеографических обстановок в геологическом прошлом авторы придерживаются схем и карт, предложенных K.P. Скотизом (C.R. Scotese) с коллегами [34 и др.].

\section{Докембрий (4,5 млрд - 535-542 млн лет назад)}

Геологическая история Земли насчитывает порядка 4,5 млрд лет. Бо́льшая часть этого времени практически не охарактеризована органическими остатками. Поэтому этап развития органического мира от момента формирования Земли (более 4,5 млрд лет назад) до 535 млн лет назад, времени появления довольно сложно устроенных организмов, называют криптозоем, или временем «скрытой» жизни (om

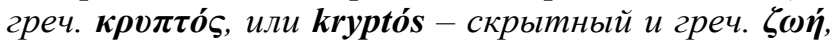
$\boldsymbol{z о e}$-жизнь). В противоположность криптозою выделяется время «явной» жизни - фанерозой (от др.-греч.

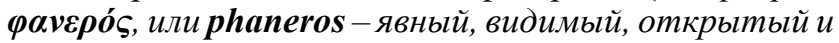

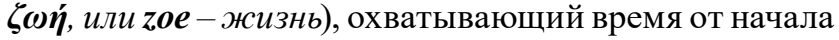
кембрийского периода (начала палеозойской эры) до настоящего времени. В фанерозойских отложениях мы встречаем многочисленные ископаемые остатки высокоорганизованных животных, обладавших минеральным скелетом, и многоклеточных растений.

\section{Вендский период (600 - 535-542 млн лет назад)}

В конце криптозоя, когда растительность была представлена, видимо, только низшими растениями (водорослями), а в морях появились первые многоклеточные животные, не имевшие еще минерального скелета, - выделяется вендский период. Венд назван так по наименованию древнейшего славянского племени венедов, обитавших с I по VII-VIII вв. н. э. по берегам Вислы и побережью Балтийского моря. Эту систему выделил крупнейший отечественный палеонтолог академик Борис Сергеевич Соколов (19142013, рис. 2).
Как это ни парадоксально звучит, но «в венде» жители и гости Петербурга бывают практически каждый день, в большинстве случаев сами того не подозревая. Дело в том, что большая часть Петербургского метрополитена проложена именно в плотных зеленовато-синих глинах вендского возраста, называемых «ламинаритовыми» (важно не путать их с синими кембрийскими глинами, о которых речь пойдет ниже). Еще Э.И. Эйхвальд [30] описал «перепончатые, широкие стебли» из этих глин в окрестностях Ораниенбаума и дал им название - Laminarites antiquissimus. Находили эти остатки в XIX и начале XX в. также на реке Ижоре недалеко от нынешней железнодорожной станции «Ижорский завод». Название Laminarites происходит от названия современной бурой водоросли Ламинарии (Laminaria) морской капусты, и было дано этим ископаемым благодаря внешнему сходству: Laminarites встречается в виде тонких бурых пленок на поверхностях напластования глин (рис. 3). Ширина этих пленок достигает нескольких сантиметров, они всегда имеют угловатое очертание и неяснозернистую структуру [24]. Считалось, что мельчайшие бугорки на поверхности Laminarites - это их крохотные органы размножения, или спорангии - мешочки, в которых созревали споры этих растений. В процессе бурения в разные годы остатки ламинаритовых пленок были обнаружены на глубине 60-100 м во многих местах города: под гостиницей «Европейская», на Фонарном переулке, Измайловском проспекте, Крестовском острове, в районе парка Лесотехнической академии, в Купчино. В окрестностях города их можно найти в береговых обнажениях Черной речки на станции Большая Ижора (Ломоносовский район), по берегам других речушек, впадающих с юга в Финский залив, а также в целом ряде периодически возникающих в результате деятельности человека котлованов, канав и пр.

Было доказано [3, с. 102], что ламинаритовые пленки представляют собой не самостоятельное растение, а тончайшие прослои глин, обогащенные сапропелевым органическим веществом. Исходным матери-

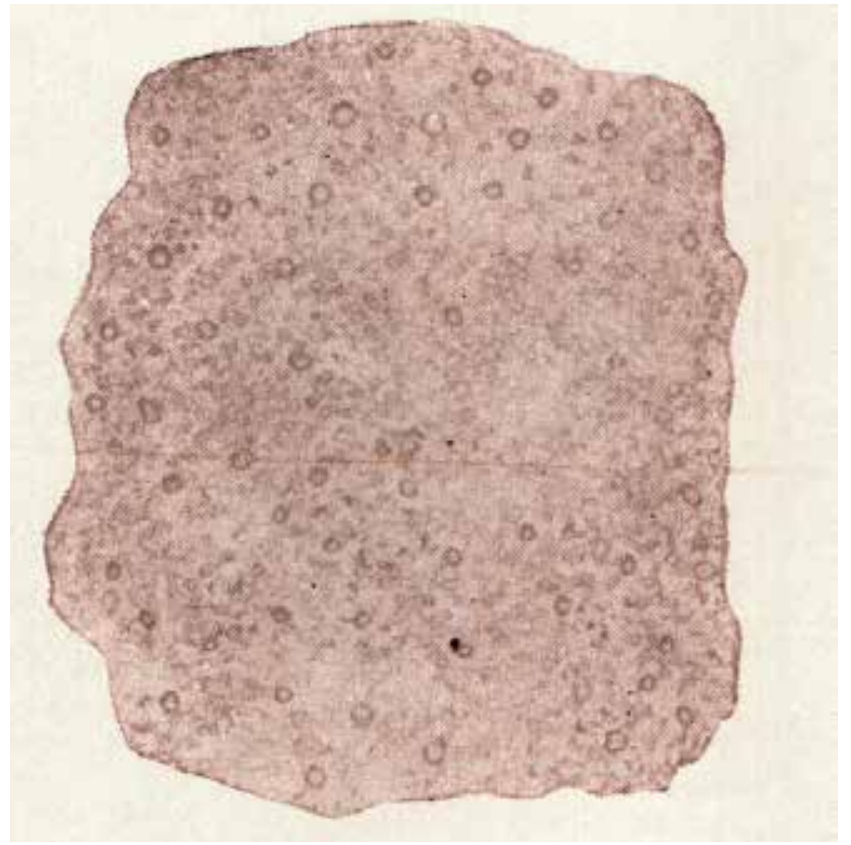

Pис. 3. Laminarites antiquissimus Eichwald (по [24, табл. I, рис. 1]) - натуральная величина 
алом для этого органического вещества могли служить достаточно высокоорганизованные растения, может быть даже полуводные или наземные. Так что теперь название Laminarites относится скорее к определенному способу сохранности органического вещества, а не является названием какого-либо определенного растения.

В тех же вендских глинах сначала М.Э. Янишевский [31], а затем Б.В. Тимофеев [24] обнаружили в скважине в Красном Селе фрагменты узких дихотомирующих лент, отдаленно напоминающих плауновидные растения. Но их истинную - водорослевую - природу доказала дочь и коллега академика Б.С. Соколова Марина Борисовна Гниловская [3-5]. Сотрудничая в течение ряда лет с Ленинградским метрополитеном, она имела возможность изучать разрезы вендских глин в строящихся тоннелях метро и работать на отвалах этих глин в разных частях нашего города. Эти водоросли получили название Vendotaenia (Вендотения), от вендской системы. Интересно, что Vendotaenia были достаточно высокоорганизованными водорослями, которым была свойственна тканевая многоклеточность.

Vendotaenia (рис. 4, 5) образовывали заросли, состоявшие из упругих, эластичных, почти не ветвящихся лентовидных слоевищ длиной более $15 \mathrm{~cm}$ при ширине до 4 мм [1]. Они обитали на илистом или песчаном дне неглубокого спокойного вендского моря, северный (в современной ориентировке) берег которого образовывали еще не разрушенные горные сооружения нынешнего Балтийского щита. В венде территория теперешнего Северо-Запада России находилась в умеренных широтах южного полушария (если смотреть по современной карте, то примерно на уровне северной части пролива Дрейка).

В тех же вендских осадках, а также в кембрийских и ордовикских отложениях сохранились микроскопические остатки организмов неясного систематического положения - акритархи (Acritarcha, om дp.-греч. akritos - сомнительный, неясный и arche - происхождение) [24 и многие другие работы]. Они представляют собой крошечные (до нескольких сотен микро-

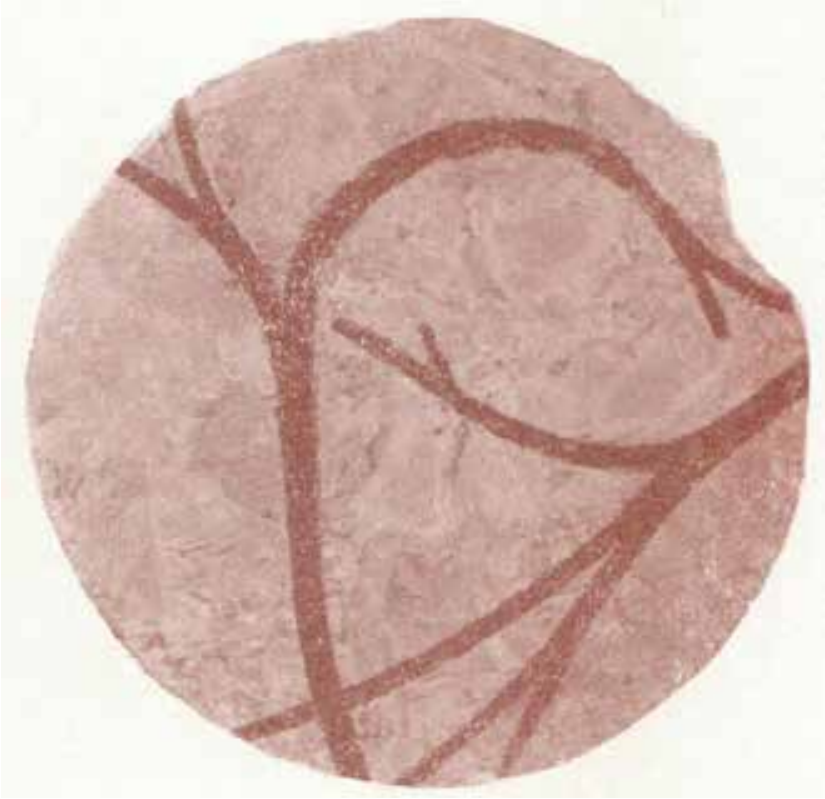

Puc. 4. Vendotaenia antiqua Gnilovskaya (по [24, табл. I, рис. 2a]) нов в диаметре) сферические образования; некоторые из них гладкие, другие на поверхности снабжены всевозможными бугорками и шипиками, многие из которых ветвятся на концах (рис. 6). Большинство исследователей склоняется к их растительной природе и рассматривает акритархи как цисты водорослей.

Встречаются акритархи почти повсеместно в отложениях протерозоя и фанерозоя, исчезая из геологической летописи лишь в начале четвертичного периода. На территории Санкт-Петербурга и его окрестностей акритархи можно встретить где угодно, ведь город стоит на венде и кембрии (южная часть города). Проблема заключается в том, что для их извлечения из породы необходима специальная методика растворения, отмучивания, отбора и изучения этих объектов при помощи бинокуляра или микроскопа.

Микроскопические остатки акритарх имеют очень важное значение для установления относительного возраста горных пород, для их сопоставления (корреляции) на больших расстояниях. В настоящее время акритархи являются одной из наиболее широко изучаемых групп ископаемых организмов.

\section{Палеозой.}

Кембрийский период (535-542 - 490 млн лет назад)

В кембрийском периоде на большей части территории нынешнего Северо-Запада России было сравнительно мелкое и спокойное море, на дне которого также обитали различные водоросли. Их разрозненные остатки можно встретить в синих кембрийских глинах в районе пос. Саблино, по берегам реки Ижоры близ пос. Войскорово, в карьерах - в пос. Никольское на р. Тосна, близ Колпино и в ряде других мест. Эти остатки представляют собой мелкие обрывки углефицированных и пиритизированных фрагментов, измененных настолько сильно, что определить их не представляется возможным. Судя по особенностям строения глинистой толщи нижнего кембрия, можно судить лишь о том, что в начале кембрийского периода обстановки на дне моря были приблизительно такими же, как и в конце вендского периода.

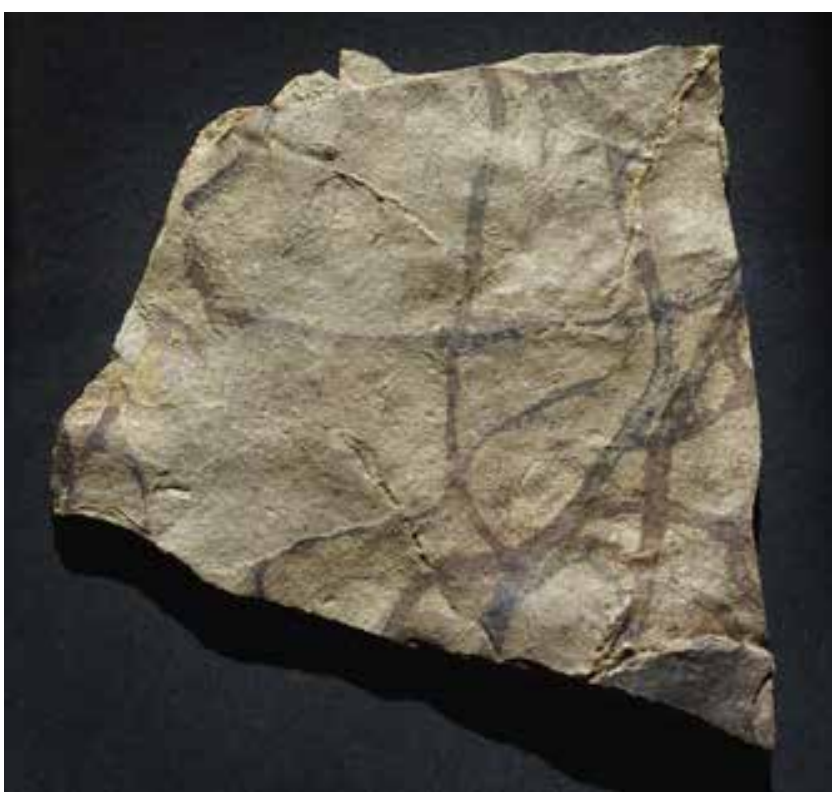

Pис. 5. Лентовидные слоевища Vendotaenia antiqua, натуральная величина (материал из коллекции Э.А. Морозова, фото предоставлено Э.А. Морозовым) 
Ордовикский период (490-443 млн лет назад)

Наиболее известны и широко посещаются специалистами и палеонтологами-любителями выходы ордовикских отложений Ленинградской области. Самыми «популярными» ископаемыми ордовика являются трилобиты - палеозойские членистоногие, питавшиеся илом и растительным детритом. На последних словах заострим внимание: какие растения являлись тем материалом, при размельчении которого образовался растительный детрит? Скорее всего, источником пищи для морских животных служили какие-то водные растения. Например, хорошо известны известковые водоросли, участвовавшие в постройках так называемых «геккеровых ${ }^{1}$ горбов»первых рифовых построек на территории нынешнего Северо-Запада России [25]. Не менее хорошо известны сохранившиеся в ордовикских отложениях до наших дней обызвествленные (инкрустированные карбонатом кальция) «шарики» зеленых водорослей, схожих с современными сифонеями (рис. 7). Первоначально их принимали за остатки морских пузырей (иглокожих животных), широко развитых в нижнем и среднем ордовике Северо-Запада России, о чем свидетельствуют, например, названия Cyclocrinus и $C y$ clocrinites (окончание -crinus и его вариации характерны для названий многих иглокожих).

В более «высоких» уровнях ордовикской системы в западной части Ленинградской области и в северной Эстонии широко известны находки остатков удиви-

1 «Геккеровы горбы» названы так по имени крупнейшего палеонтолога, палеоэколога и геолога Романа Федоровича Геккера (1900-1991), впервые обнаружившего и описавшего эти образования, наблюдающиеся в разрезах в виде положительных структур - «горбов» - на дне древнего ордовикского моря.

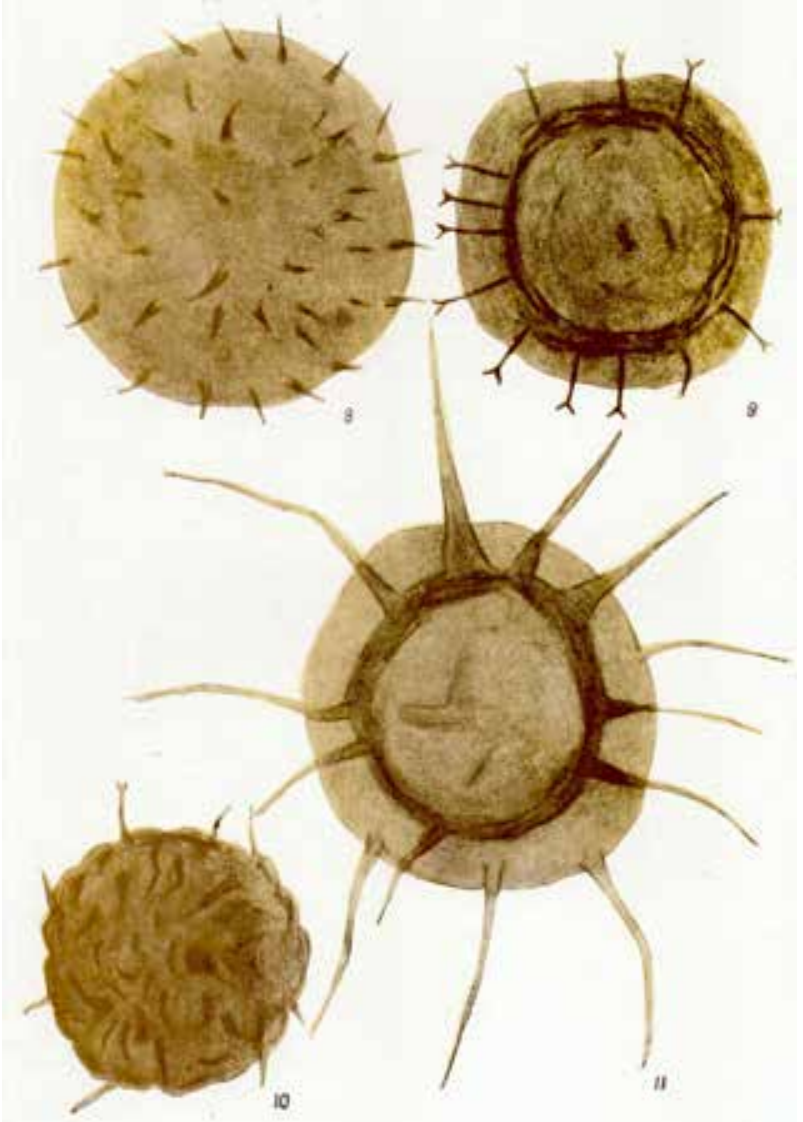

Рис. 6. Акритархи (по [24, табл. IV, фиг. 8-1 1]). Диаметр объектов от 66 до $102 \mu$ тельных организмов - рецептакулитов (Receptaculita, от лат. receptaculita - вместилище, хранилище), порою формирующих так называемые «рецептакулитовые известняки» (рис. 8). Впервые описанные как шишки хвойных растений, они впоследствии были переизучены и рассматривались как отдельный класс типа Spongiata (губки). Ряд исследователей предлагали выделять их в самостоятельный тип древних животных, представляющих тупиковую ветвь эволюции. Систематическое положение и природа рецептакулитов до сих пор не установлены с уверенностью, однако в палеонтологической литературе они зачастую рассматриваются среди водорослей, и изучением их занимаются в основном палеоальгологи - специалисты по ископаемым водорослям.

И все же находки ископаемых остатков растений в ордовикских отложениях на Северо-Западе России очень редки. Иногда встречаются редкие обугленные обрывки, по которым невозможно понять их систематическую принадлежность. Слабая в целом палеоботаническая изученность нашего ордовика все же позволяет надеяться на появление новых интересных данных. Одной из таких уникальных находок может являться ископаемое (растение?), обнаруженное недавно коллегами в Эстонии, изображение которого (рис. 9) мы приводим пока что без названия и описания, так как не располагаем первичным материалом, необходимым для его изучения.

В 2007 г. С.В. Наугольных обнаружил на берегах реки Волхов в районе Волховстроя отпечаток новой фитофоссилии: Volkhoviella primitiva (Волховиелла примитивная). Volkhoviella представляла собой очень примитивное растение, сочетавшее внешние признаки риниофитов и некоторых современных лишайников (рис. 10). Ее остатки были найдены в отложениях с признаками субаэрального происхождения, а наличие у этого растения плотных покровов свидетельствует в пользу того, что оно могло произрастать в наземных условиях. Примитивность строения Волховиелль, вместе с ее исключительно большой древностью, указывает на то, что она располагается где-то в самом основании древа наземных растений [12, с. 41].

На западе Ленинградской области практически на границе с Эстонией находится город Сланцы, названный так благодаря месторождениям горючих
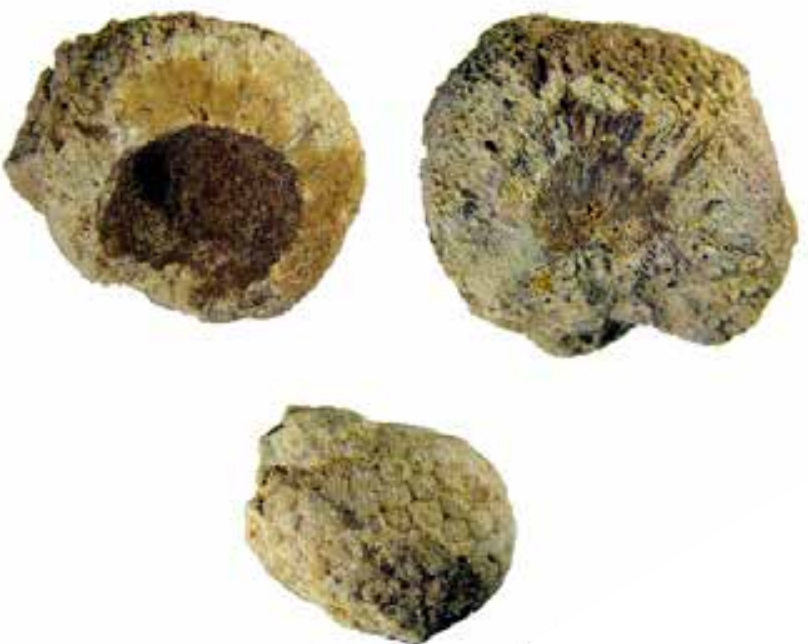

Pис. 7. Cyclocrinus (внизу) и Cyclocrinites Eichwald (вверху) из ордовикских отложений Ленинградской области. Размеры образцов - около 1 см в поперечнике каждый (http://www. ammonit.ru/foto/44207.htm) 


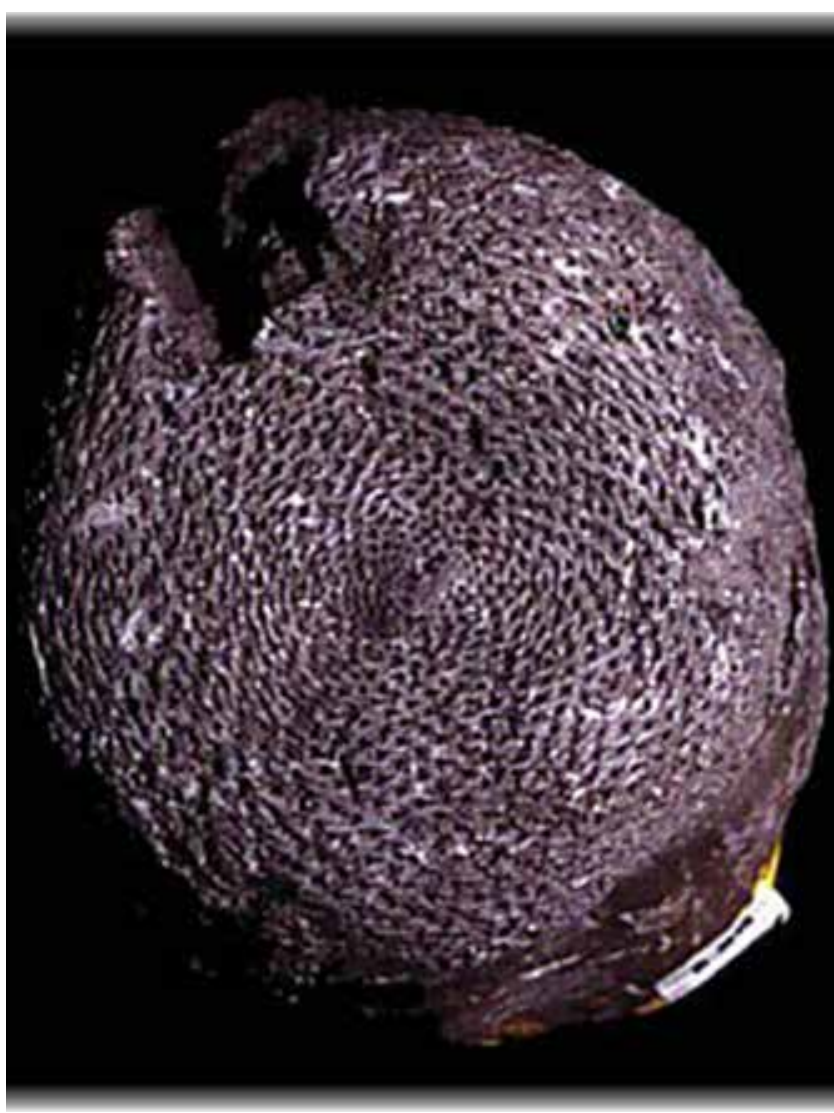

Рис. 8. Ордовикский Рецептакулит, натуральная величина (http://evolbiol.ru/_pproblem.htm)

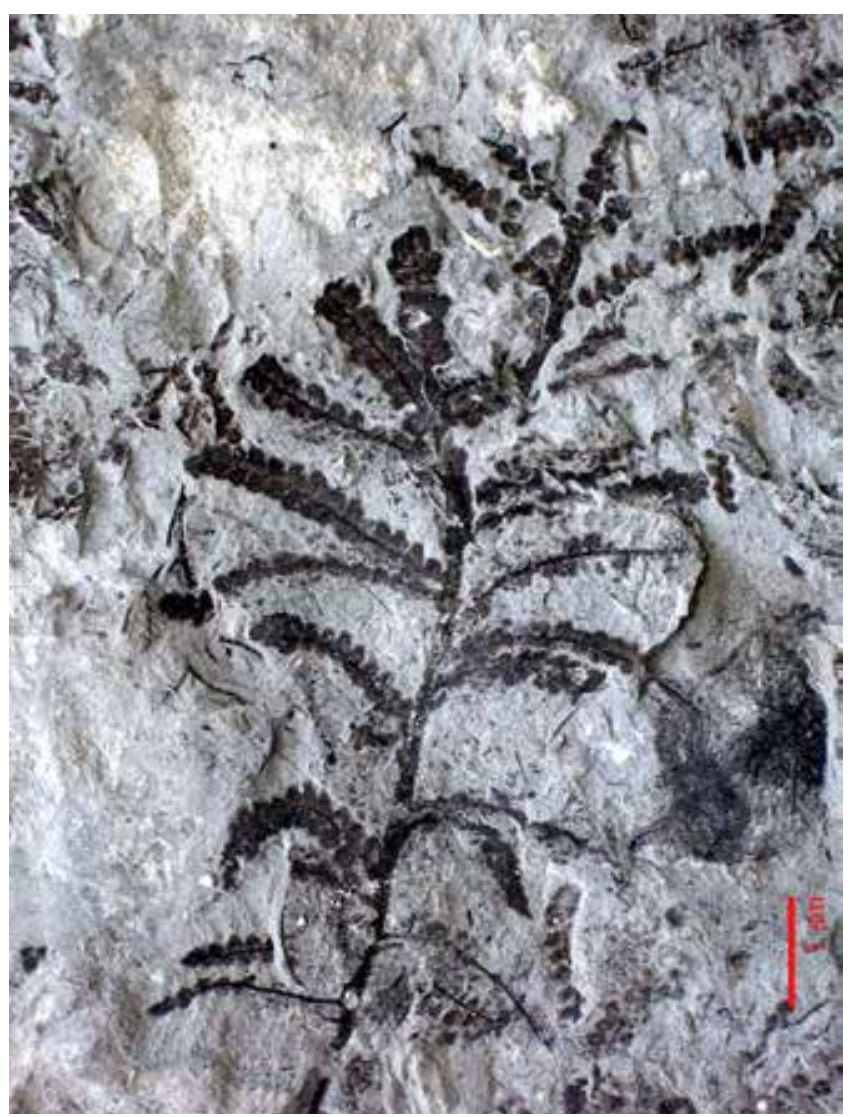

Рис. 9. Уникальное ископаемое (растение?) из ордовика Эстонии (фотография О.О. Долгова)
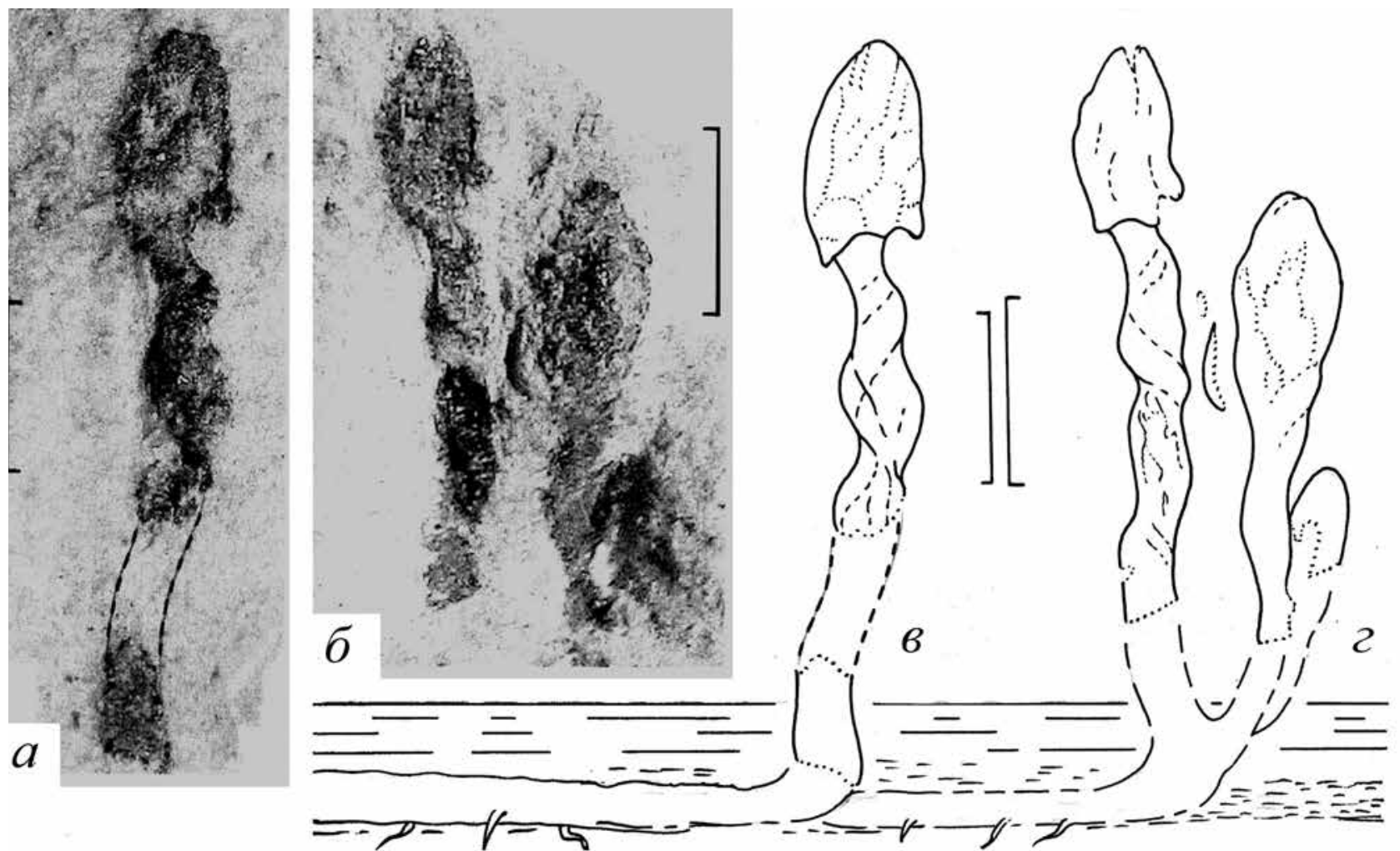

Pис. 10. Volkhoviella primitiva Naugolnykh: a - фертильный побег, после дополнительной препарации; 6 - два фертильных побега до препарации; в, г - графическая дешифровка общего облика растения и предполагаемая интерпретация прикрепления фертильных побегов к горизонтальным столонам. Средний ордовик, близ г. Волховстроя. Длина масштабной линейки 1 мм. (Фотографии любезно предоставил С.В. Наугольных; материалы хранятся в коллекции ГИН РАН) 


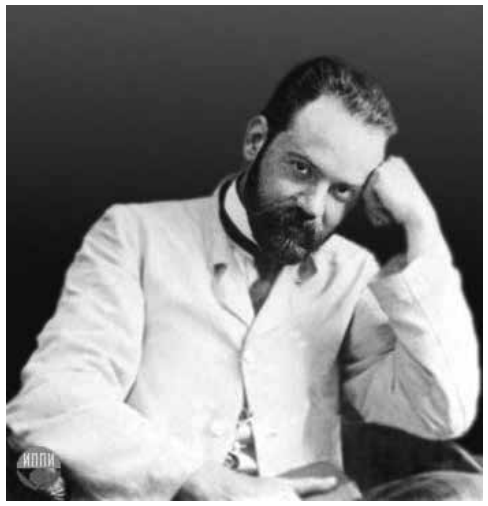

Рис. 11. Михаил Дмитриевич Залесский (1877-1946)

сланцев - «кукерситов» - в отложениях среднего ордовика. Многочисленные шахты и реже карьеры вскрывают мощную толщу кукерситов - коричневатых тонкодисперсных пород, содержащих большое количество органического вещества. Еще в начале $\mathrm{XX}$ в. крупнейший отечественный палеоботаник Михаил Дмитриевич Залесский (1877-1946, рис. 11) детально исследовал образцы этого горючего сланца и пришел к выводу о том, что это - сапропелит, образовавшийся в морском бассейне благодаря активной жизнедеятельности зеленых водорослей [8]. Вся порода состоит исключительно из остатков самих микроскопических водорослей, без примеси минеральных частиц. Если сделать шлифы из кусков кукерсита, можно увидеть, что в сильно измененной основной массе рассеяны многочисленные колонии мелких шарообразных водорослей (рис. 12), названных М.Д. Залесским Gloeocapsomorpha prisca - по сходству с современной водорослью Gloeocapsa.

М.Д. Залесский [8, с. 15-16] такими словами описывал возможные условия образования кукерсита: «Принимая водоросль Gloeocapsomorpha prisca за форму планктонную или живущую в илу ввиду мощности слоев, которые она способна была образовать вопреки морфологическим признакам ее, напоминающим современных... Gloeocapsa, покрывающих слизистым покровом увлажняемые скалы на берегу, ...можно представить себе такую же экологию и для Gloeocapsomorpha prisca. Если допустить, что сильные волны ударялись о скалы, покрытые толстым слизистым покровом этой водоросли, и срывали с них в массе ее слизистые колонии, унося их в море, и по успокоении его в короткий срок отлагали эти взвешенные в воде частицы на дно, то вопрос сводится только к тому, может ли таким способом образоваться пласт породы в 3 фута толщины. .. Допустить это возможно в том случае, если представить себе продолжительное и сильное действие волны на берег и быстрое возмещение водорослей на берегу путем нарастания новых слизистых покровов их. В этом случае отдельный пласт кукерсита мог бы получиться как результат большой бури или целого ряда следовавших один за другим бурных дней, или наконец целого бурного периода в году, во время которого море обогащалось этою водорослью в громадном количестве».

В то время (1917 г.) научная интуиция М.Д. Залесского не была достаточно подкреплена данными о существовании штормов в ордовикском море Русской платформы. Лишь существенно позже, после осмысления большого фактического материала, А.В. Дро- новым с коллегами было доказано, что большая часть ордовикских пород здесь сформировалась в условиях штормового осадконакопления, что подтверждает приведенные выше рассуждения известного палеоботаника. В те времена Балтоскандинавский бассейн располагался на $45-60^{\circ}$ ю. ш., соленость моря была нормальная (около 35-36\%), а воды - умеренно-холодными [25].

\section{Силурийский период (443-418 млн лет назад)}

Осадочные породы, имеющие возраст от позднего ордовика до начала среднего девона, на территории нынешнего Северо-Запада России отсутствуют, и никаких свидетельств о растительной или животной жизни на этой территории у нас не имеется. Может быть, эти территории покрывало море, осадки которого были размыты впоследствии? Но если здесь была суша, то на обширной равнине, прилегавшей к склонам Балтийского щита, могла развиваться первая наземная растительность...

\section{Девонский период (418-360 млн лет назад)}

Девон - наверное, самый удивительный период в развитии наземных растений. В его начале суша была практически пустынна, лишь редкие водные и полупогруженные в воду растения обитали по берегам морских лагун и широких дельт рек. Закончился девонский период совсем по-другому: шумели на ветру первые леса Земли, хелицеровые (из членистоногих) вполне освоились под пологом леса, земноводные стали первыми позвоночными на суше.

На территории Ленинградской области известны средне- и верхнедевонские отложения, содержащие три группы очень своеобразных ископаемых организмов.

1. На речке Поповке, которая впадает недалеко от Павловска в р. Славянку, можно видеть классические разрезы ордовика и девона, уже более 200 лет привлекающие к себе исследователей. Весьма интересны среднедевонские мергели, переполненные трохилисками - многочисленными остатками микроскопических оогониев харовых водорослей.

Харовые водоросли - самостоятельный отдел водорослей, представляющих собой крупные расте-

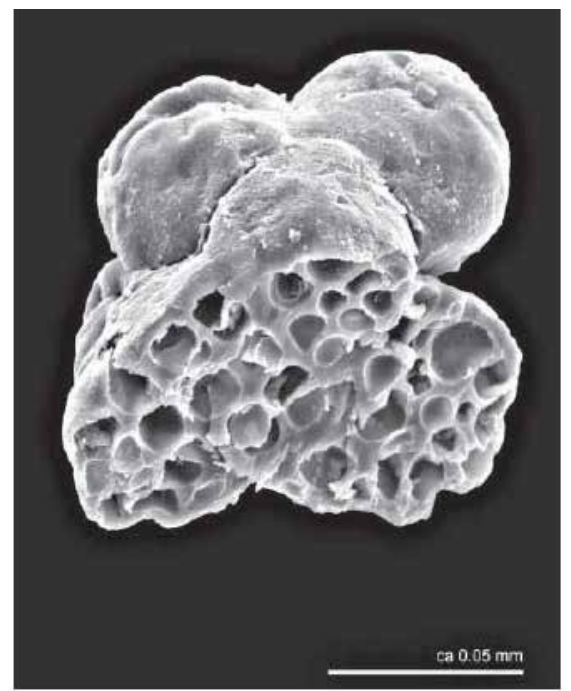

Pис. 12. Gloeocapsomorpha prisca Zalessky, сильно увеличено (http://www.geoeducation.info/geoturism/ polevkivi.php). Длина масштабной линейки - 0,05 см 


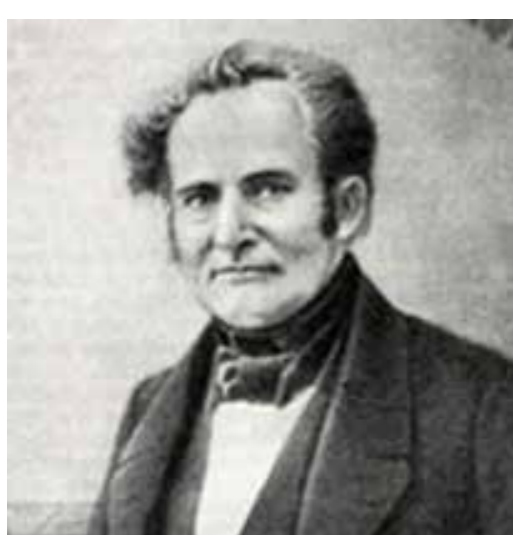

Рис. 13. Христиан Пандер (1794-1865)

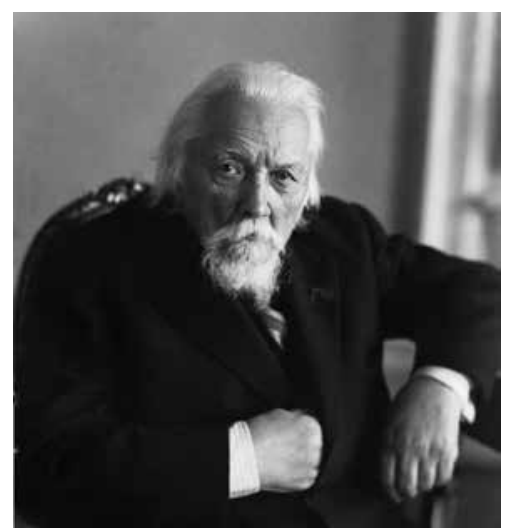

Рис. 14. Александр Петрович Карпинский (1846-1936)

ния с мутовками членистых боковых побегов (похожи на современные хвощи), обитающие в пресных водоемах и опресненных участках морей [16]. Размножение харовых осуществляется преимущественно половым путем. Эти растения продуцируют большое количество половых клеток, содержащихся в оогониях (органах размножения, в которых созревают женские половые клетки) и антеридиях (органах размножения с мужскими половыми клетками), снабженных очень прочной оболочкой, под прикрытием которой оплодотворенные ооспоры могут сохраняться годами, до наступления условий, благоприятных для их прорастания.

Trochiliscus (Tрохилискус, или трохилиски) и Sycidium (Сицидиум) - родовые названия для микроскопических оогониев, находимых в девонских отложениях земного шара. Впервые трохилиски в петербургском девоне (на р. Поповке) были обнаружены русским естествоиспытателем, палеонтологом, эмбриологом и анатомом Христианом Пандером (1794-1865, рис. 13) в середине XIX в., а впоследствии детально описаны академиком Александром Петровичем Карпинским (1846-1936, рис. 14), Президентом Академии наук сначала России, а впоследствии - и СССР [9]. Трохилиски представляют собой мелкие (до 1,5-2 мм в диаметре) карбонатные шарики со спиральной или концентрической орнаментацией. Внутри они полые, на полюсах есть малое отверстие и более крупная воронка (рис. 15).

Условия нахождения остатков трохилисков указывают, что эти водоросли обитали в водах, образуя достаточно густые заросли вдоль берегов. Эти заросли заглушали иную водную растительность, образуя моновидовые сообщества на минимальной глубине (от 0,1 до 3, максимум 5 м).
В окрестностях Петербурга трохилиски, помимо речки Поповки, найдены также на р. Тосне выше водопада; в валуне на р. Мсте у д. Льзи (Новгородская обл.); в окрестностях г. Изборска Псковской области; на р. Сяси около д. Юхоры; в деревнях Марьино, Поповка, Пязелева, Аннолово, Кобралово, Тайцы; на реках Ижоре, Волхове, Лемовже, Оредеже, Луге.

2. Самые загадочные ископаемые среднего девона в окрестностях Петербурга - нематофиты. В ископаемом состоянии они выглядят достаточно обычно - крупные «стволы» длиной иногда до нескольких метров и диаметром до полуметра. Встречаются часто в песчаных отложениях по берегам р. Луги и ее притоков, а также в других районах распространения среднедевонских осадков песчаного состава. Но на срезе под микроскопом видно, что это - не ствол дерева и вроде вообще не растение. Древесина высших растений всегда состоит из тонких длинных проводящих клеток - трахеид или сосудов (последние преобладают у цветковых растений). Имеется также целый комплекс иных тканей (запасающих, покровных и т. д.). Все они имеют характерные признаки, хорошо заметные на различных срезах - поперечном, радиальном и тангентальном. Нематофumbl же состоят из трубок, напоминающих скорее мицелий гриба, нежели древесину высшего растения (рис. 16).

Впервые остатки этих удивительных организмов были описаны из девона Северной Америки шотландским палеоботаником сэром Джоном Вильямом Доусоном (J.W. Dawson, 1820-1899, рис. 17) в 1859 г. Первоначально он называл их Prototaxites (Прототакситес), думая, что они были предками хвойных; затем Nematoxylon и Nematophyton (Нематоксилон и
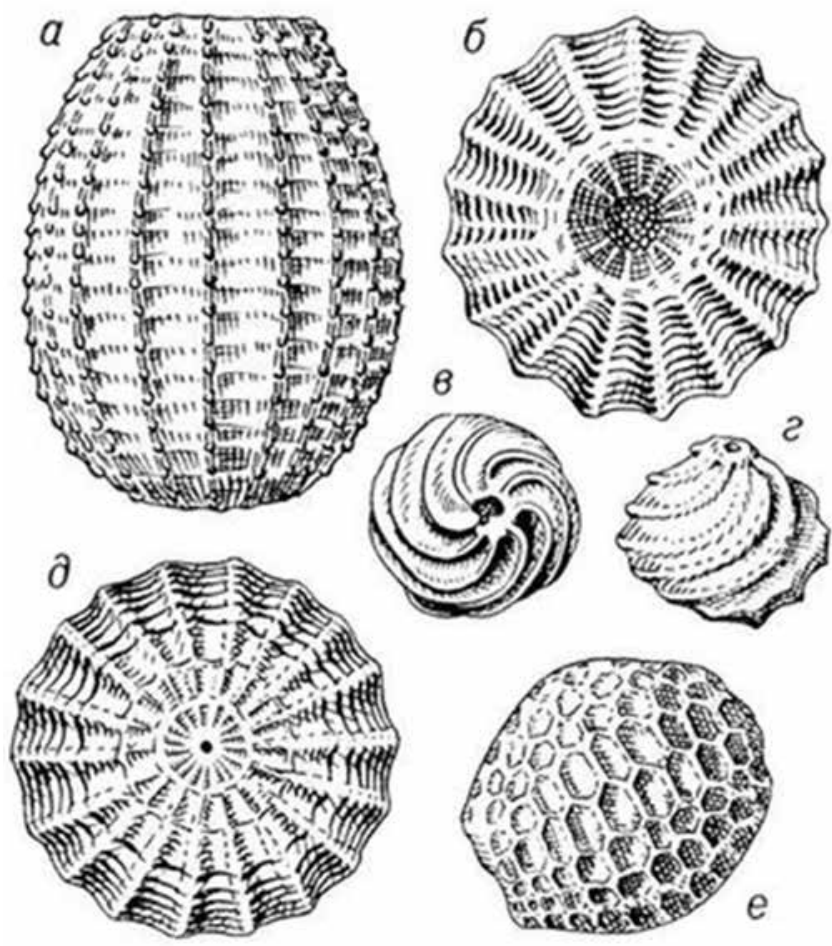

Рис. 15. Обызвествлённые оогонии харовых водорослей Sycidium (a, 6, д, е) и Trochiliscus (в, r) из девонских отложений Ленинградской области, сильно увеличено. (http://bse.scilib.com/particle019421.html) 
Нематофитон). Существует еще целый ряд родовых названий для этих остатков, находимых в разных частях света. Наиболее употребительными являются два названия - Prototaxites и Nematophyton. Долгое время считалось, что эти остатки представляют собой стволы каких-то наземных растений, скорее всего, гнилую древесину хвойных; рассматривали их и в качестве бурых водорослей. И лишь недавно, на рубеже XX-XXI вв. американский палеоботаник Френсис Хьюбер (Francis Hueber) установил [32], что Prototaxites представлял собою гигантский гриб, достигавший нескольких метров в длину. Созданы реконструкции (рис. 18), выглядящие достаточно неправдоподобно, на которых изображены гигантские грибы, достигавшие в высоту до 9 метров! Едва ли можно считать такие реконструкции обоснованными. Для того чтобы такой гриб удержался на суше в

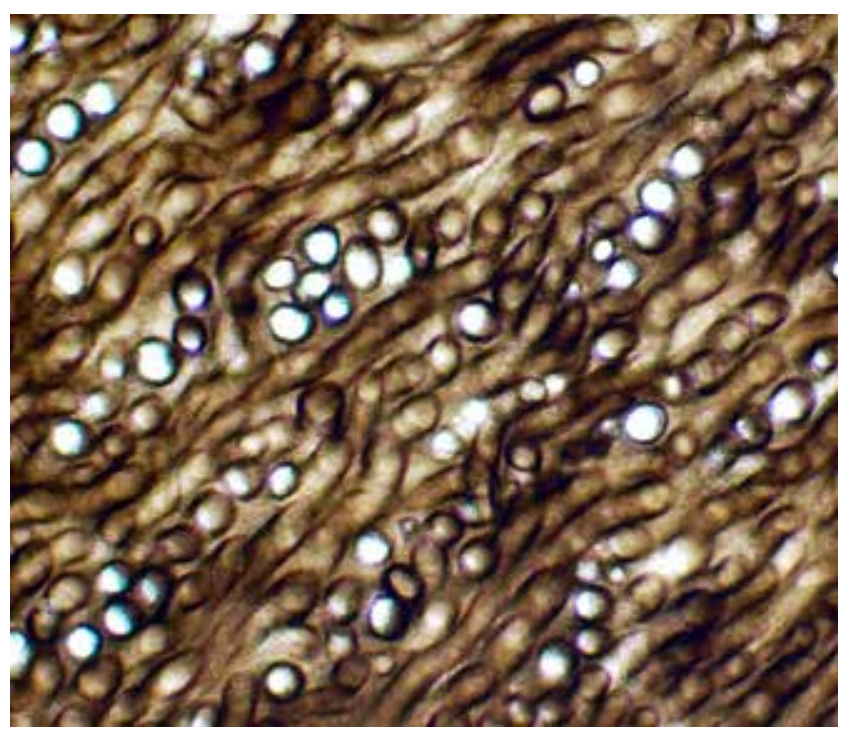

Рис. 16. Микроструктура Prototaxites в световом микроскопе, сильно увеличено. (https://en.wikipedia.org/ wiki/Prototaxites\#/media/File:Prototaxm 10.JPG)

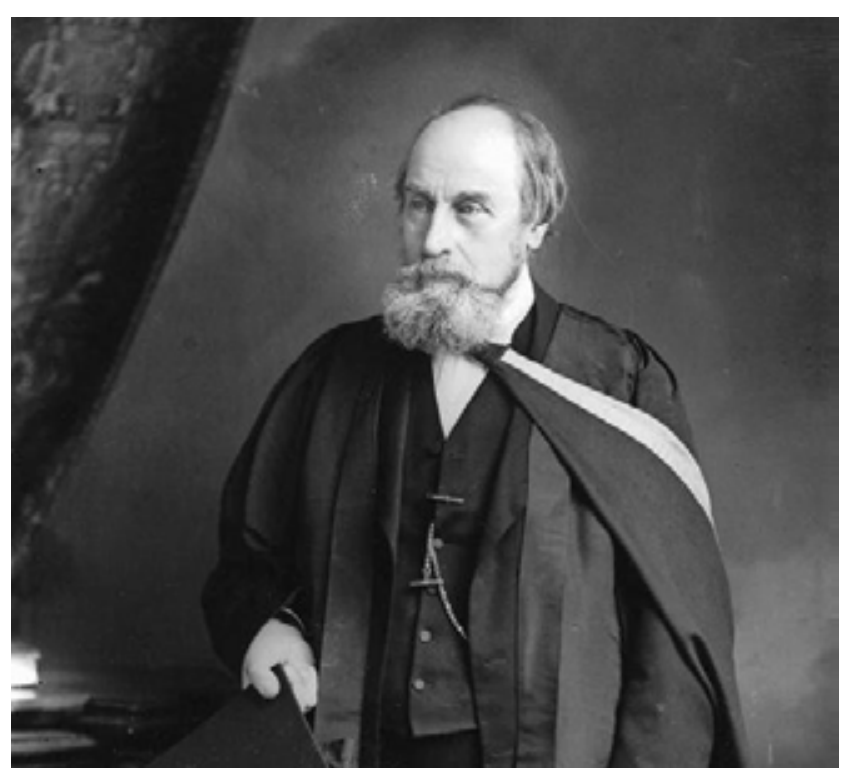

Рис. 17. Сэр Джон Вильям Доусон (J.W. Dawson, 1820-1899)

вертикальном положении, ему нужна была или внушительная опора, или значительное одревеснение его основных тканей. Hо у Prototaxites не было ни того, ни другого. Поэтому допустить его вертикальное положение на земной поверхности не представляется возможным. Известно, что любая асимметрия в строении организмов свидетельствует об их неравномерном развитии во все стороны. Обнаруженная асимметрия структуры поперечного среза «стволов» Prototaxites (рис. 19) свидетельствует о том, что они не были ориентированы вертикально, а могли быть ползучими формами, иногда слегка приподнимавшимися. Нам кажется наиболее правдоподобным, что эти организмы были погружены в грунт или в воду, удерживаясь в донном субстрате с помощью ризоидов, подобно современным гигантским бурым водорослям. Они могли также расти в неглубоких де-

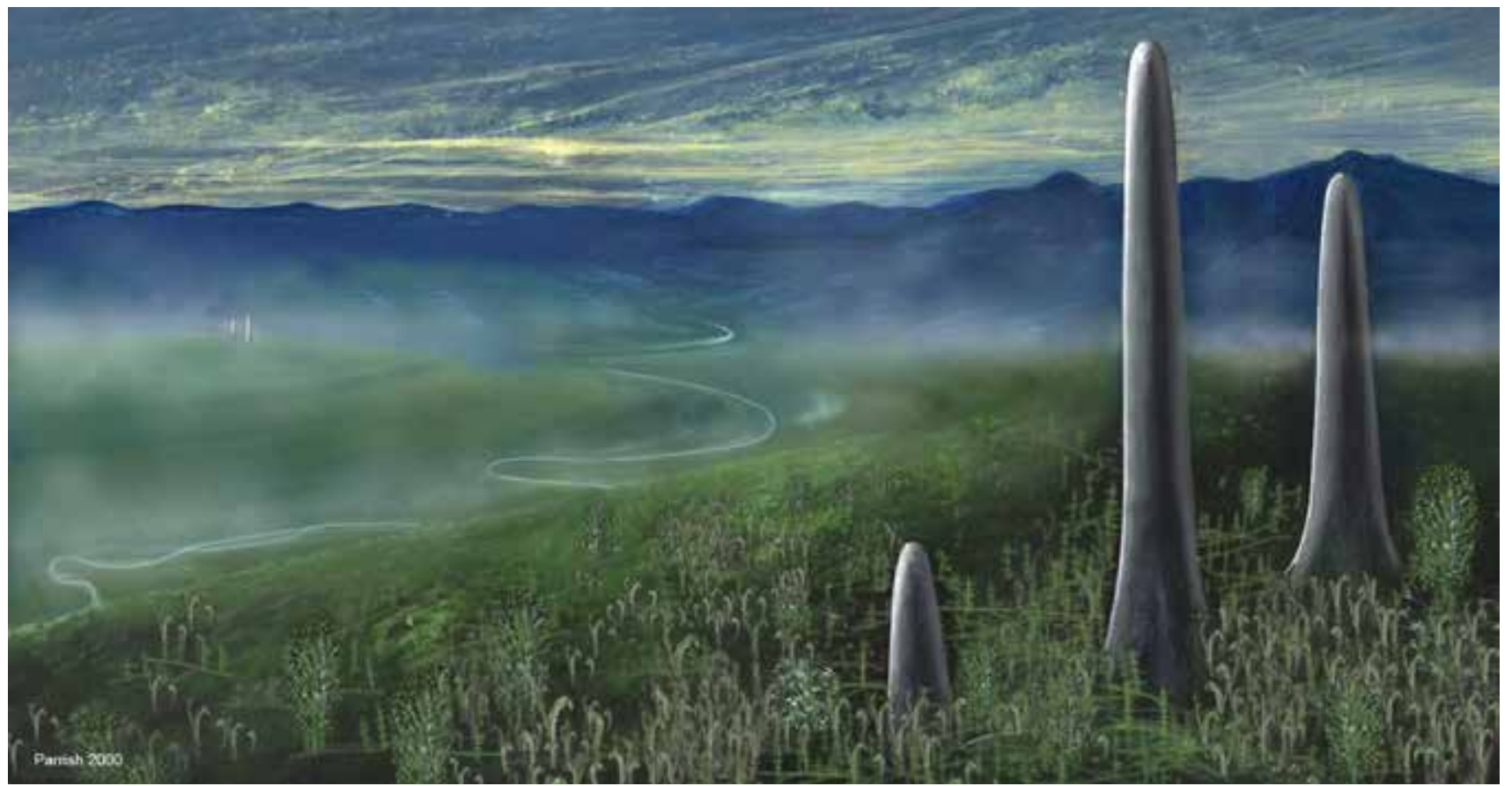

Рис. 18. Реконструкция раннедевонского ландшафта с Prototaxites (рисунок Mary Parrish, National Museum of Natural History) 
прессиях и расщелинах скал в условиях достаточной увлажненности.

Подробнее с многочисленными данными исследований по проблеме Prototaxites - Nematophyton можно ознакомиться на сайтах $x s 4 a l l . n l$ и www.membrana.ru.

На основании сказанного можно представить себе среднедевонский ландшафт нынешнего Главного Девонского поля ${ }^{2}$, по большей части занятого мелким морем, на востоке (в нынешней ориентировке) которого находилась полого наклоненная к морю равнина, а на севере - отроги размывавшегося Балтийского щита. По берегам располагались обширные болота, которые совсем не походили на привычные для нас: в девоне не было аналогов современных верховых болот, да и низинными их тоже назвать было бы нельзя. Это были отшнурованные участки моря или дельт рек с застойной водой и слегка заиленных. По мелководьям и берегам таких озер-болот, наверное, и протягивались гигантские плодовые тела девонских грибов Prototaxites.

3. В отложениях Главного девонского поля хорошо сохранившиеся остатки высших растений достаточно редки, однако здесь неоднократно встречаются обломки окаменевших, замещенных кремнеземом или карбонатом кальция, древесин Apхеоптерисов (не путать с Археоптериксами - первоптицами). Листовые остатки Archaeopteris (Apxeоптерис, или «древний папоротник») были впервые описаны в 1871 г. из верхнего девона Северной Америки уже упомянутым J.W. Dawson, а древесины этих растений - в 1911 г. из верхнего девона Донбасса М.Д. Залесским под родовым названием Callixylon (Калликсилон). Интересно, что лишь в 1960-е гг. американский палеоботаник Чарльз Бек (Ch. Beck) доказал, что Archaeopteris и Callixylon - части одного и того же растения. Спустя еще 20 лет стало понятно, что Apхеоптерисы были первыми лесообразующими растениями Зем-

${ }^{2}$ Главным Девонским полем называют комплекс отложений девонского возраста, участвующих в формировании осадочных пород, слагающих Московскую синеклизу. На поверхность породы Главного девонского поля выходят в Ленинградской, Вологодской, Новгородской, Псковской областях.

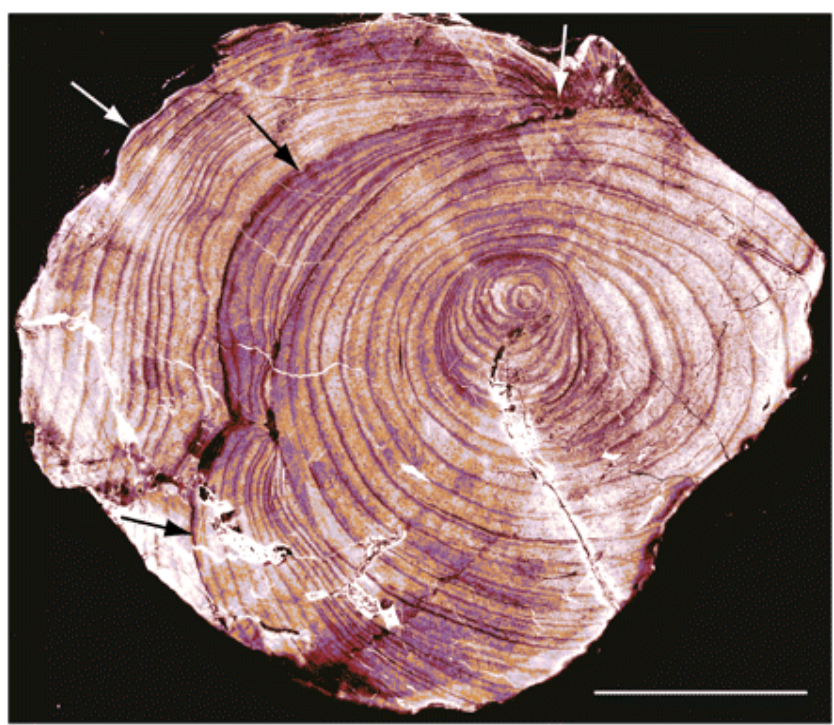

Рис. 19. Поперечный разрез «стебля» Prototaxites c отчетливо заметной асимметрией (http://www.maryanningsrevenge.com/2013/12/awesome-dead-shit-prototaxites.html) ли, и именно им мы обязаны формированию лесов как природного явления [17-19]. После проведения нами в 1980-1981 гг. детальных работ на классических местонахождениях Callixylon в Донбассе стало возможным составить полную реконструкцию этих растений (рис. 20).

Apхеоптерисы были совершенно самостоятельной группой растений, они не имели и не имеют аналогов в растительном мире Земли. Характер проводящей системы этих растений был наиболее благоприятным для жизни их в достаточно засушливых местах; способность камбия к ритмической деятельности позволяла легко переносить неблагоприятные сезоны года; образование настоящих листьев, закладывавшихся в спиральной последовательности, способствовало формированию огромной фотосинтезирующей поверхности; характер ветвления приводил к

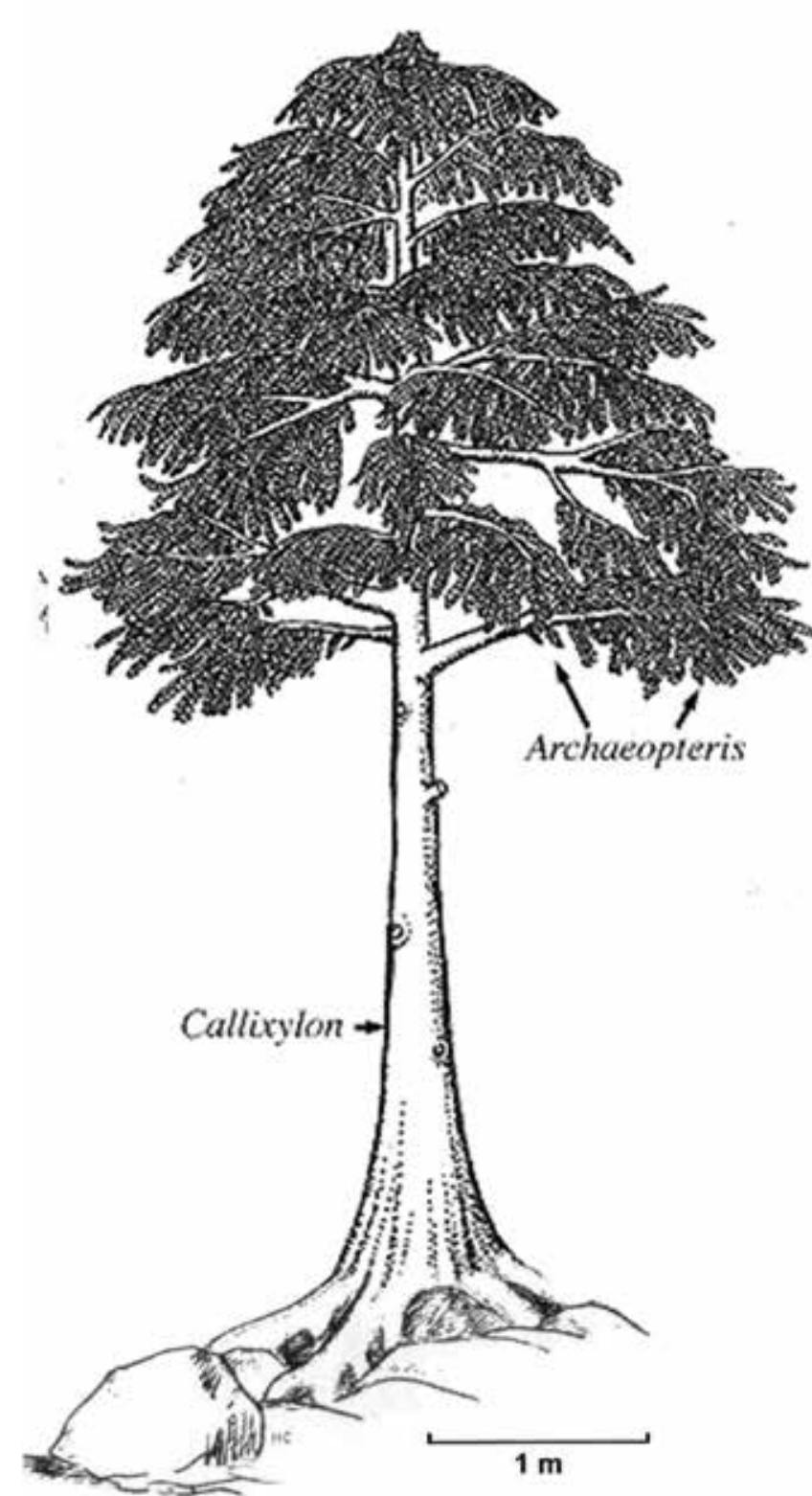

Рис. 20. Реконструкция Archaeopteris (составлена по материалам Berkley Museum of Paleontology и собственным материалам авторов) 


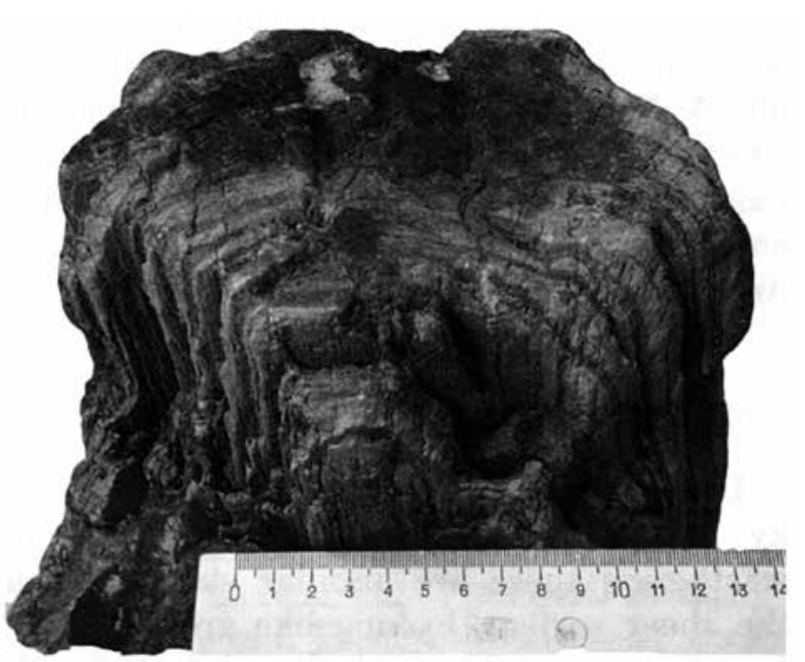

Pис. 21. Фрагмент ствола Callixylon из верхнедевонских отложений Андомы горы (Онежское озеро) (коллекция ПМ-СПбГУ, по [35])
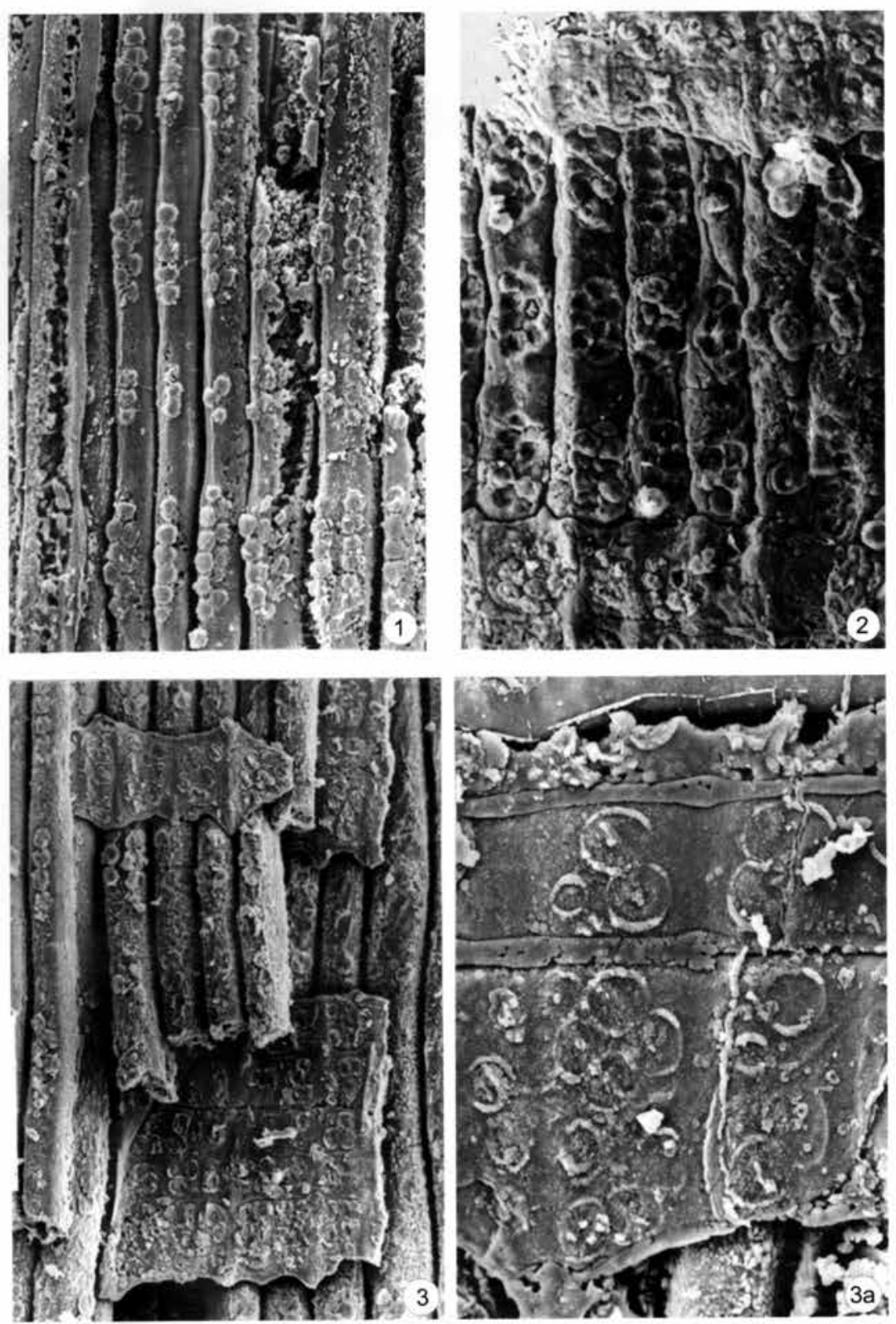

Рис. 22. Микроструктура древесины, изображенной на рис. 21. Фиг. 1, 2, 3 - увеличение х150; 3а - увеличение х500. Микрофотографии выполнены на сканирующем электронном микроскопе JSM-6390 LA в центре коллективного пользования БИН РАН, гл. специалист Л.В. Карцева (коллекция ПМ-СПбГУ, по [35]) 
образованию достаточно обширной кроны; метельчатые собрания спороношений, хотя и были достаточно примитивны в эволюционном отношении, но позволяли рассеивать споры на достаточно большие расстояния. Эти удивительные растения просуществовали на Земле менее всех других крупных групп растительного царства - только поздний девон, всего около 20 млн лет. За столь короткий срок они подготовили почвенный слой достаточной мощности и продуктивности для проникновения растительных сообществ в глубь суши, создали такой широко распространенный ныне тип растительных формаций, как леса [21].

Apхеоптерисы, одни из первых растений «настоящей» суши, то есть утратившие необходимость в воде как среде обитания, были поставлены в очень жесткие условия. К моменту их появления на Земле (в конце среднего девона) активно развивались преимущественно процессы химического и механического выветривания. Биологическое выветривание имело, очевидно, подчиненное значение. Первые лесообразующие растения Земли являлись в первую очередь хорошими почвообразователями. Не исключено, что присущая Археоптерисам веткопадность (см. рис. 20) служила дополнительным источником биомассы, поступавшей в круговорот питательных веществ и увеличивавшей объем гумуса в первичных лесных почвах.

В девоне нынешний Северо-Запад России находился в приэкваториальной области, что было весьма подходящим для археоптерисовой флоры. Леса покрывали высоко воздымавшийся Балтийский щит и его отроги, особенно густые заросли могли тяготеть к руслам стекавших с возвышенностей рек. В современной ориентировке суша находилась к северу от Петербурга, на нынешнем Карельском перешейке и еще севернее, а море Главного девонского поля - к югу, причем берег протягивался извилистой линией, захватывая южные части нынешних Павловска и Гатчины, пересекал р. Волхов выше Волховстроя, р. Сясь у ст. Колчаново и достигал на востоке тех мест, где ныне расположено Онежское озеро и вытекающая из него р. Свирь.

Древесины Callixylon были обнаружены нами на Андомской горе на южном берегу Онежского озера (рис. 21, 22), на р. Сясь близ с. Колчаново, на р. Лемовже и в ряде других мест [35]. Из отложений, переходных от девона к карбону, на р. Мде (притоке p. Мсты) у д. Потафьево недалеко от ж/д станции Неболчи М.Д. Залесский [36] описывал остатки листьев Archaeopteris mdaensis, а также фрагменты плауновидного растения Lepidodendron moscovense (о Лeпидодендронах см. в разделе, посвященном каменноугольному периоду).

\section{Каменноугольный период (360-295 млн лет назад)}

Каменноугольные отложения на Северо-Западе России развиты не менее широко, чем ордовикские и девонские толщи. Нижний карбон вскрывается широкой полосой от Вытегры на востоке региона через Бокситогорск, Любытино, Боровичи до Окуловки и Валдая. Отложения этого возраста достаточно хорошо охарактеризованы остатками ископаемых растений.

Каменноугольный период (карбон) - первый в истории Земли период массового угленакопления. Северо-Запад европейской части России, а в гео- структурном смысле - северо-западное крыло Московской синеклизы, относится к так называемому Подмосковному угленосному бассейну. Самые близкие к Петербургу месторождения каменных углей находятся в окрестностях города Боровичи Новгородской области - в тех местах остатки ископаемых растений встречаются достаточно часто, и их палеоботанической характеристике посвящено много работ специалистов [6, 7, 10, 11, 13, 14, 20, 33 и мн. др.]. По нашим данным, в нижнем карбоне всего северного крыла Московской синеклизы встречено не менее 60 видов ископаемых древних растений (рис. 23).

В этой статье мы не будем перечислять систематический состав раннекарбоновой флоры, а охарактеризуем растительные сообщества, которые существовали по берегам моря Московской синеклизы и рек, в него впадавших. Теплый влажный тропический климат господствовал на территории нынешней Русской платформы начиная с конца девона. «Московское море» ${ }^{3}$ было мелким и теплым: в нем развивались разнообразные животные (брахиоподы, кораллы, моллюски, мшанки, трилобиты, иглокожие, различные рыбы и др.). Важную роль играли зеленые и багряные выделяющие известь водоросли, участвовавшие в формировании известняков. Берега моря были пологие, топкие; в некоторых местах в море впадали широкие медленно текущие реки, формировавшие широкие дельты с мощными конусами выноса. Приморские низменности, заливавшиеся во время приливов и обнажавшиеся во время отливов, были покрыты довольно густыми лесами, образованными древовидными плауновидными растения-

\footnotetext{
«Московским морем» мы называем морской бассейн, в котором накапливались осадочные породы, ныне слагающие Московскую синеклизу.
}

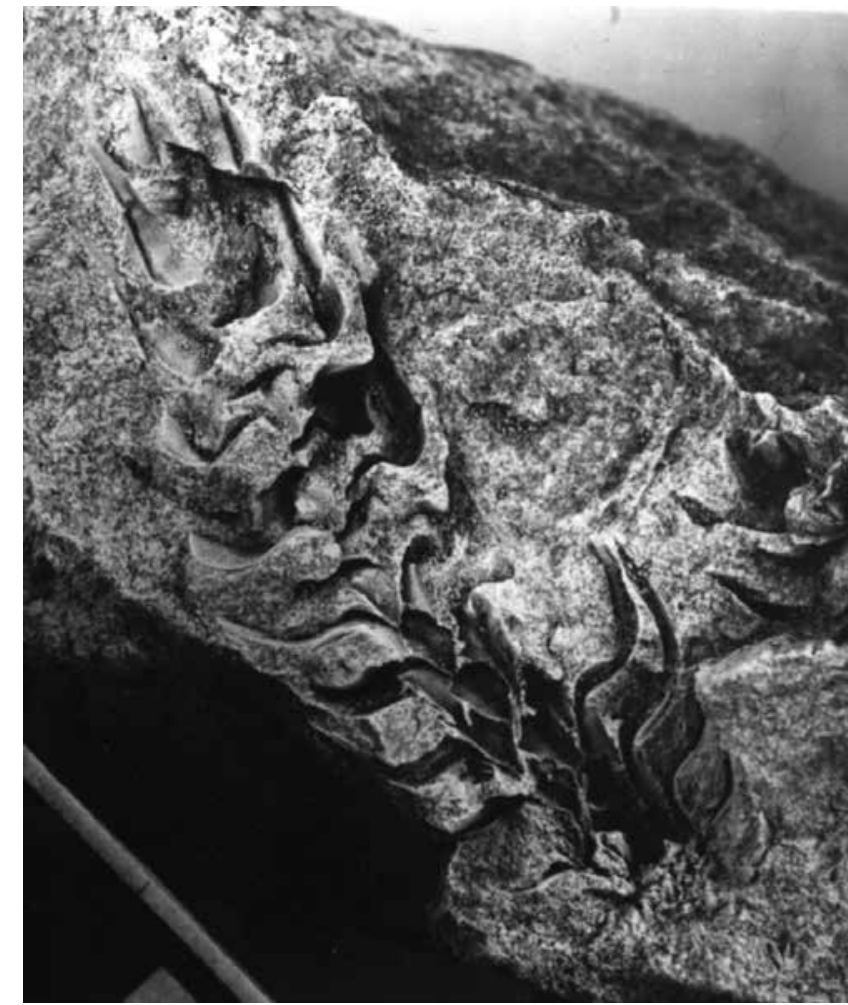

Рис. 23. Олиственный побег плауновидного растения Lусоpodites (Ликоподитес) из нижнего карбона Боровичей (сборы С.М. Снигиревского, коллекция ПМ-СПбГУ). Увеличено в 3 раза 


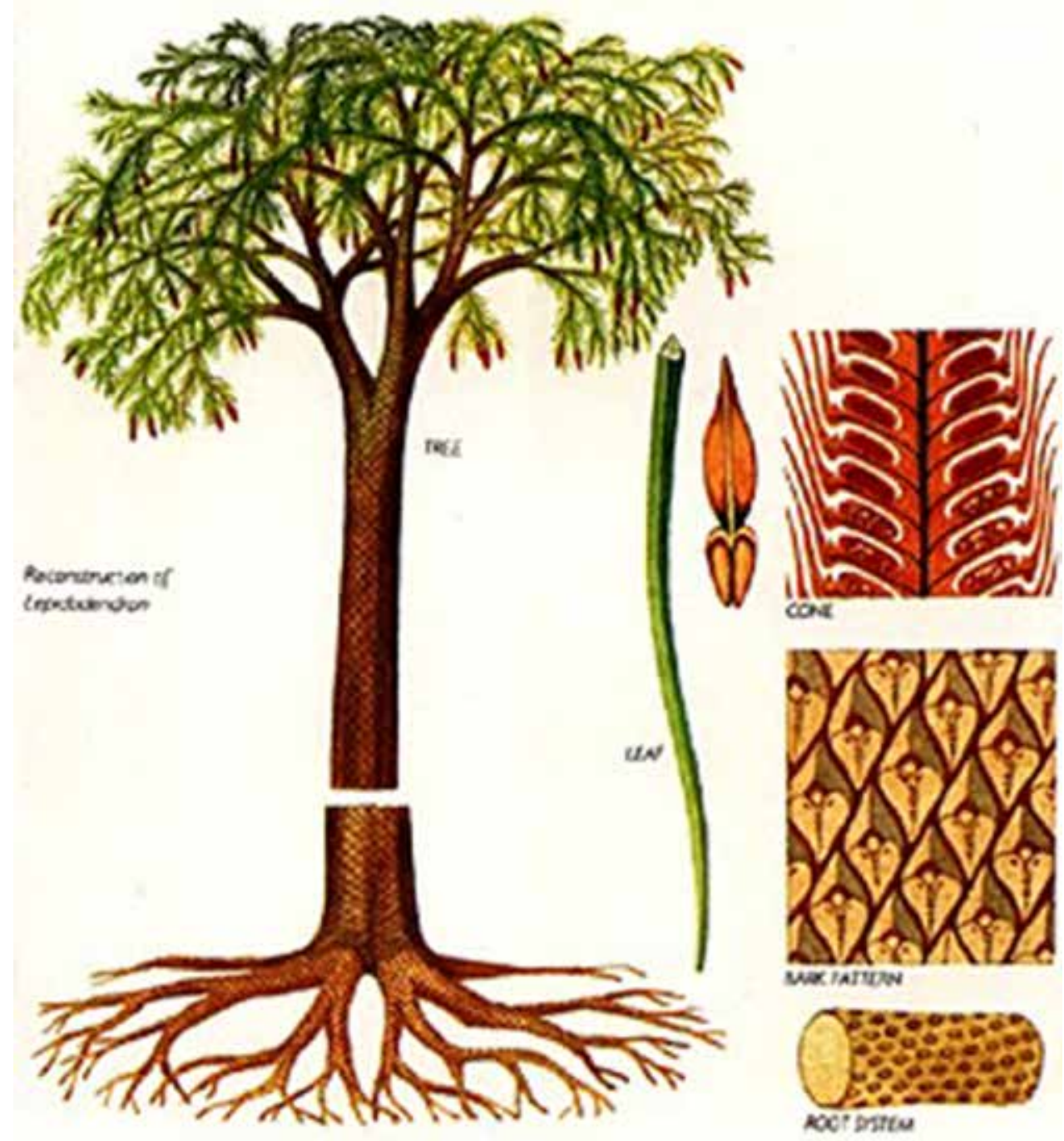

Pис. 24. Реконструкция Lepidodendron (Лепидодендрон)

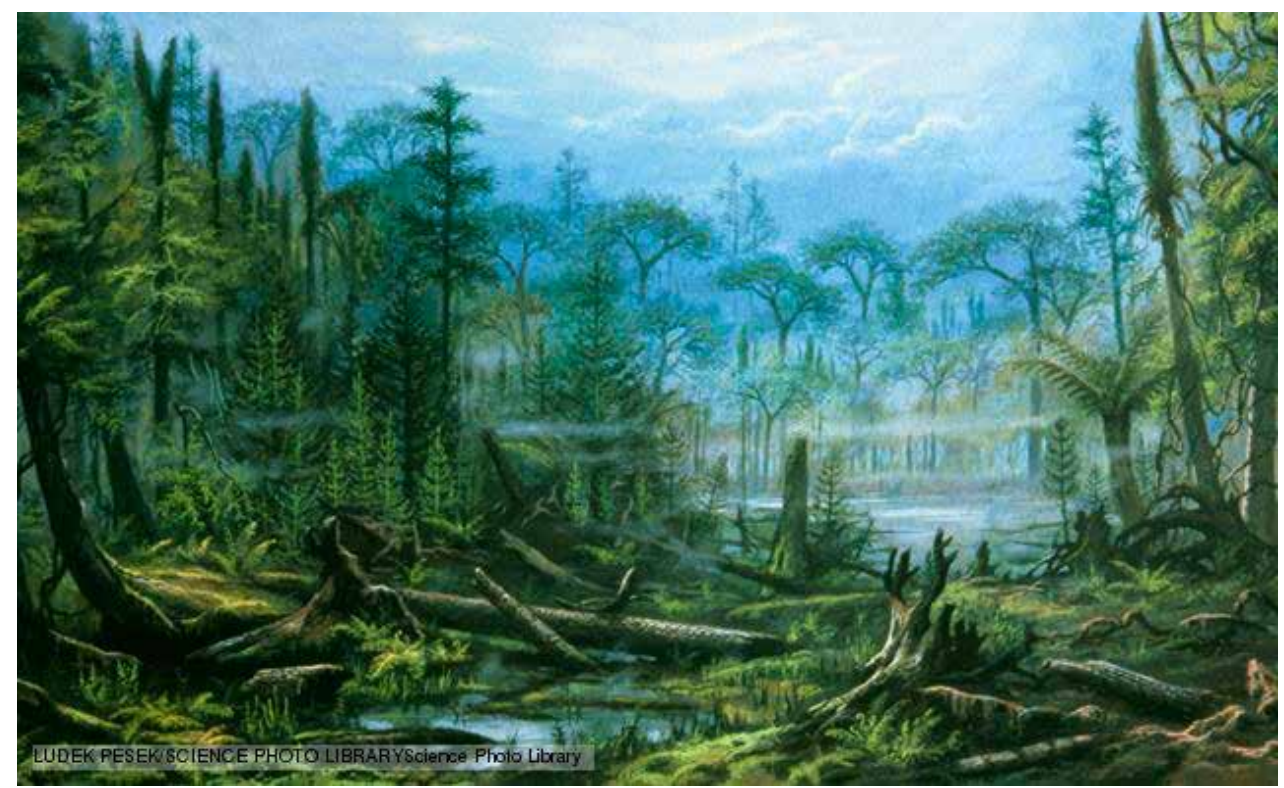

Рис. 25. Лес каменноугольного периода. Реконструкция с сайта http://www.bbc.co.uk/ nature/history_of_the_earth/Carboniferous 
ми - в основном Лепидодендронами (Lepidodendron, рис. 24). По аналогии с современными приморскими лесами, образованными мангровыми деревьями, такие древние заросли по берегам морей также называют «растительностью типа современных мангров». В дельтах и по берегам рек произрастали многочисленные членистостебельные растения - $A p$ хеокаламиты (Archaeocalamites), которые наподобие современных хвощей и камышей были наполовину погружены в воду. Именно плауновидные и членистостебельные растения были основными углеобразователями на этих территориях: в болотах с застывшей черной водой, с гигантскими стволами древесных плауновидных, упавшими от порывов сильного ветра, с пучками Археокаламитов, принесенных во время паводка и зацепившихся за торчащий из воды пень (рис. 25) - так формировались первичные торфяные залежи, которым впоследствии суждено было стать каменным углем. На более возвышенных местообитаниях - там, куда не доходили приливы и где не было вязких болот, обитали совершенно другие растения - папоротники и семенные папоротники, многие из которых были также древовидными формами. Они, по-видимому, не участвовали в углеобразовании на территории Московской синеклизы.
В нижнем карбоне Северо-Запада России встречаются в основном остатки плауновидных и реже перышки папоротникообразных растений. Их можно найти в обнажениях и карьерах по берегам рек Паша, Оять, Воложба, Мста, Волга (в ее верховьях) и их притоков [22].

Остановимся на более подробной характеристике некоторых растительных остатков нижнего карбона. Очень часто в известняках и глинистых прослоях встречаются остатки подземных органов - ризофоров (корненосцев) плауновидных растений - Стигмарии (Stigmaria). Это длинные, часто вильчато ветвящиеся подземные части плауновидных растений, к которым были прикреплены корневые органы (ризоиды) этих растений (рис. 26). При отпадении ризоидов на поверхности корненосцев образовывались округлые ямочки, благодаря которым род и получил свое название (от греч. stigma - укол, клеймо, пятно). Проникая в еще не уплотненный осадок, стигмарии широко распространялись в нем и довольно хорошо «заякоривали» огромные древовидные растения. Правда, не обладавшие хорошо развитыми механическими тканями, Лепидодендроны, у которых кора занимала большую часть диаметра стебля, при затоплении подгнивали, в результате чего не могли противостоять сильным ветрам и легко ломались чуть выше

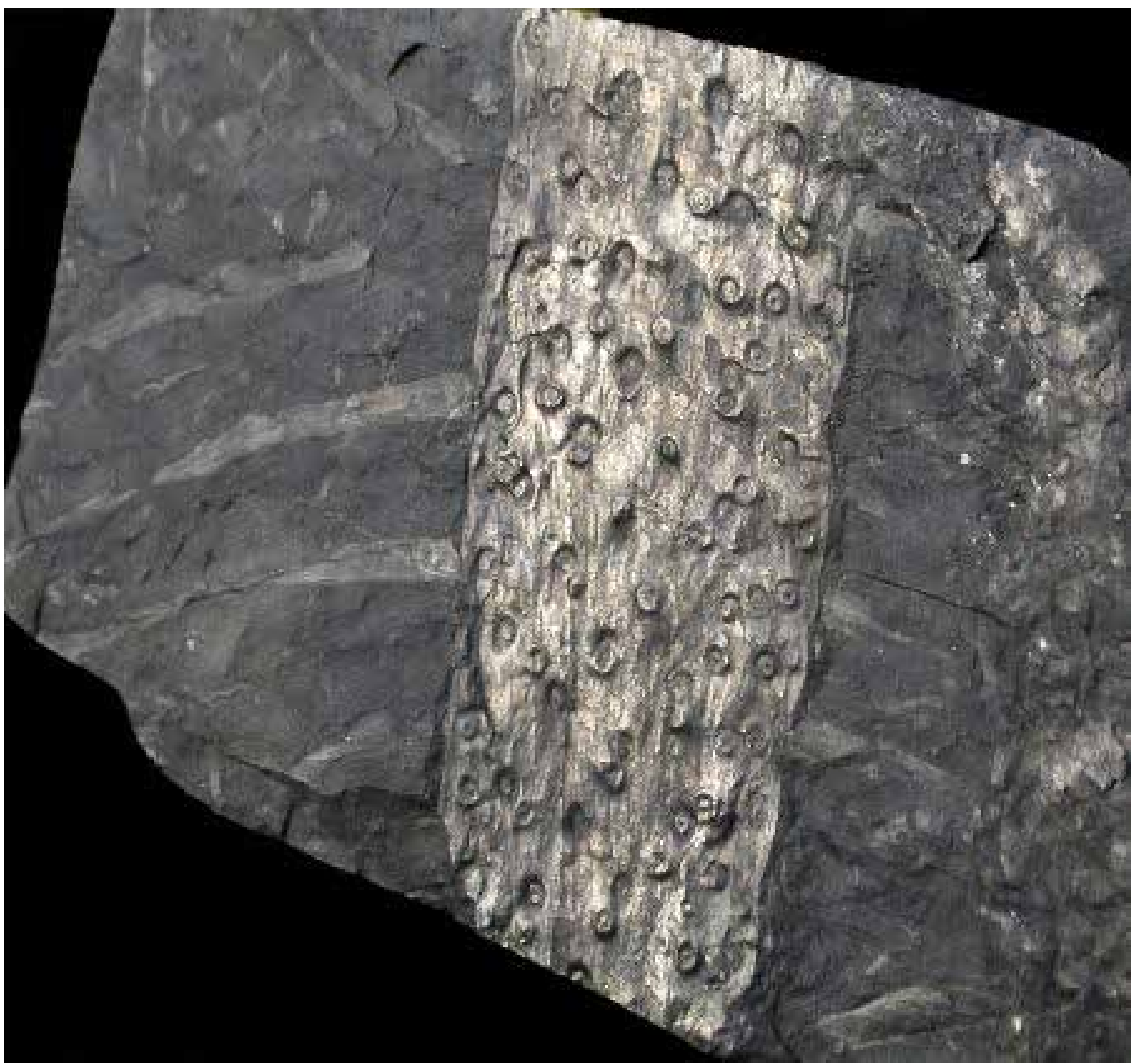

Рис. 26. Ризофор Стигмарии (Stigmaria). Натуральная величина 


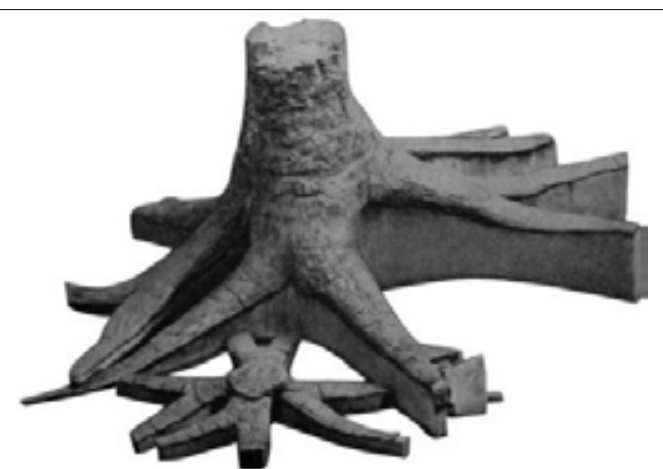

Рис. 27. Базальная часть плауновидного растения с отходящими в стороны ризофорами (корненосцами) стигмариями. (Коллекция Museum der Geol. Landesanstalt in Berlin)

основания (рис. 27). Позже торф либо превращался в уголь, либо смывался во время трансгрессий, а стигмарии оставались в осадке, на своем первоначальном месте (палеонтологи называют такой тип захоронений - in situ, или «на месте произрастания», в прижизненном положении). Именно Стигмарии - самые распространенные на Северо-Западе России остатки плауновидных. Их большое количество свидетельствует о том, что здесь в раннем карбоне были хорошо развиты описанные нами выше «сообщества типа современных мангров». Интересно, что Стигмарии разных плауновидных растений имеют одинаковые признаки, и их невозможно отличить друг от друга. Даже разные роды плауновидных растений имели одинаковые ризофоры (корненосцы), в изолированном виде всегда называемые Стигмариями.

Хотелось бы упомянуть о находке в 1999 г. на р. Рагуше отпечатка стебля загадочного растения Eleutherophyllum mirabile (от лат. mirabilis - удивительный). Это первая находка представителя этого вида в России [22]. Растение было удивительно тем, что соединяло в себе признаки сразу двух крупных групп растений - плауновидных и членистостебельных. Оно встречается весьма редко, но отмечено в Западной Европе, Китае, а теперь и в России (рис. 28). Фрагментарность остатков этого растения не позволяет, однако, дополнить что-либо к уже известным сведениям.

Пермский период (295 млн лет назад) - Неогеновый период (1,8 млн лет назад)

После раннего карбона море навсегда покинуло территорию нынешней Ленинградской области. К сожалению, никакими данными о геологической истории этого региона в течение последних 320 млн лет мы не располагаем. Скорее всего, Северо-Запад Русской платформы был очень медленно размывавшейся сушей, на которой развивались, сменяя друг друга, различные природные сообщества. Если и имелись какие-либо следы их здесь пребывания, то и они были уничтожены в четвертичном периоде, когда ледник, как бульдозер ножом, срезал с поверхности мощные толщи горных пород...

Четвертичныци период (1,8 млн лет назад - по настоящее время)

В Санкт-Петербурге и его окрестностях наиболее хорошо охарактеризованы ископаемыми остатками растений отложения четвертичного возраста.

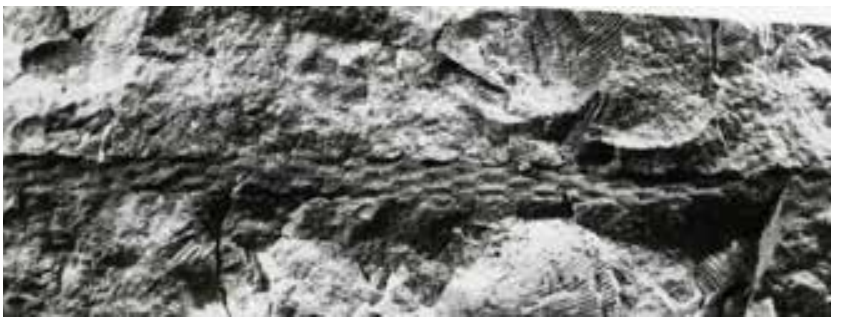

Рис. 28. Фрагмент стебелька Eleutherophyllum mirabile (Элеутерофиллюм мирабиле) из нижнекаменноугольных отложений реки Рагуша (Бокситогорский р-н Ленинградской области) на плитке известняка с отпечатками морских животных - брахиопод. (Сборы С.Ю. Енгалычева, коллекция ПМ-СПбГУ.) Увеличено в 3 раза

Остатки наземных и водных высших растений, а также различных водорослей очень часто встречаются в осадочных породах, которые обнажаются в оврагах и береговых обрывах Невы, ее притоков и других рек региона, а также вскрытых скважинами различной глубины. В четвертичном периоде на территории нашего города, да и всего северо-запада Европы, существовало несколько оледенений, во время которых наблюдались значительные изменения растительного мира под влиянием менявшегося климата, циркуляции атмосферы, изменений гидрографической сети и др. Края ледников не оставались постоянными - а значит, пределы распространения растительности, оказавшейся перед фронтом покровных оледенений, постоянно менялись. Растительный покров суши, развивавшийся вдоль края ледников, то отступал к югу, то вновь надвигался на территории, освободившиеся ото льда. С переходом от оледенений к периодам межледниковий соответственно менялся и состав флоры, элементы которой сохранились до нашего времени и встречаются в Санкт-Петербурге и его окрестностях.

В четвертичных осадках самого разного происхождения наиболее часто распространены микроскопические ископаемые остатки растений - рассеянные в породах споры и пыльца высших растений, а также жившие в различных водоемах диатомовые водоросли (Bacillariophyta или Diatomeae - диатомовые водоросли - группа микроскопических одноклеточных организмов (рис. 29), клетки которых образуют «разделенный надвое» кремнеземный панцирь очень затейливой формы). На основании изучения диатомей, нередко переносимых водами из одного бассейна в другой, можно судить о степени опресненности водоемов и даже о температурном режиме.

По спорам и пыльце судят о составе и зональных типах растительности суши и их последовательной смене в течение четвертичного периода.

Очень много для ознакомления с растительным миром плейстоцена и голоцена (надразделов четвертичного периода), существовавшим на территории города и его окрестностей, дает исследование остатков растений - пыльцы, плодов и семян, стеблей и листьев, погребенных в торфяниках, которые накапливались в периоды межледниковий и в послеледниковое время.

Растительные остатки доледникового времени в Петербурге и его окрестностях не известны, однако 


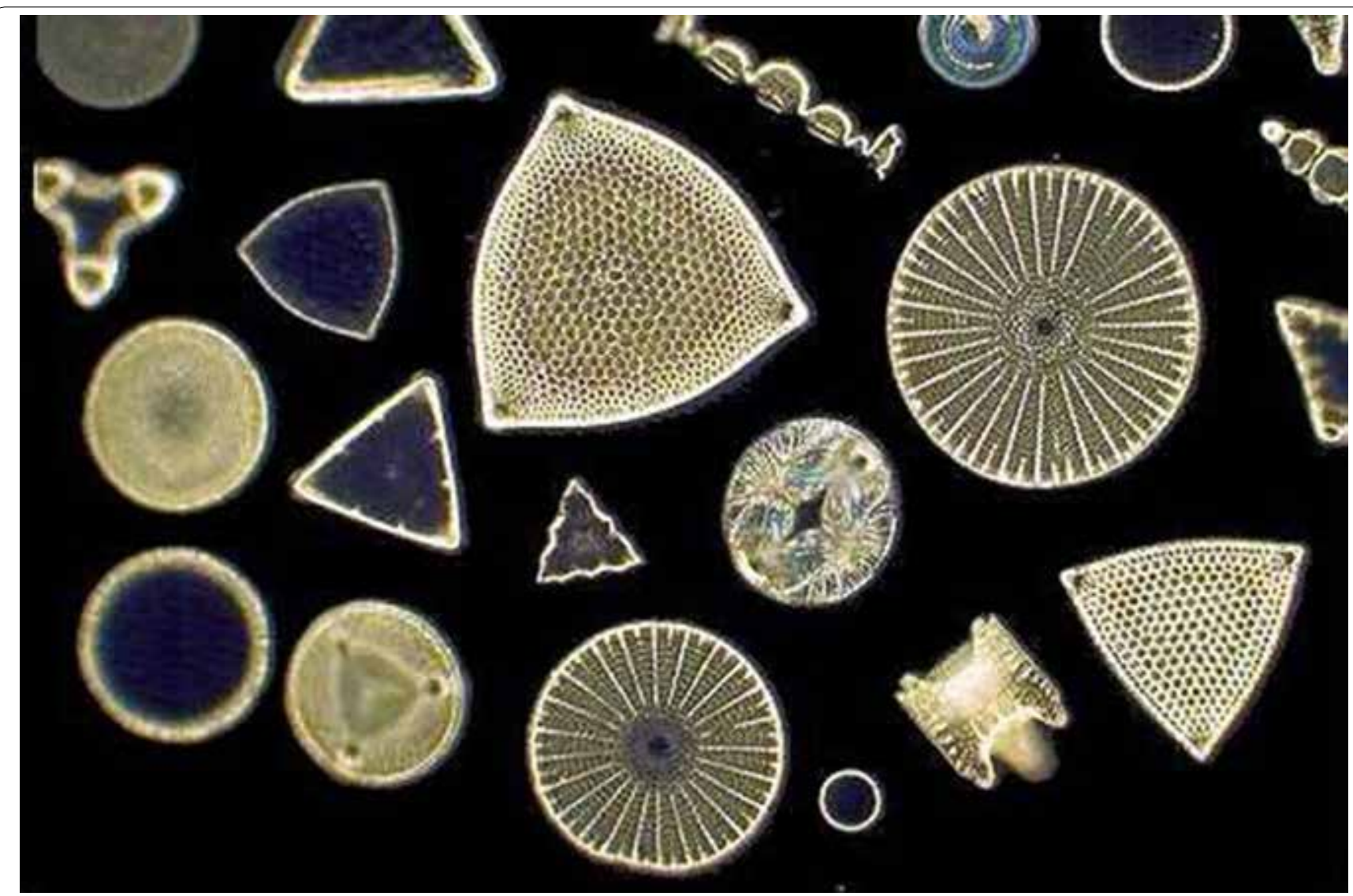

Рис. 29. Современные диатомовые водоросли. Сильно увеличено. Фото с сайта www.micrographia.com

на основании находок пыльцы сосны и ели в доледниковых отложениях смежных территорий предполагают, что тогда здесь произрастали еловые и сосновые леса таежного типа.

О растительном мире эпох трех первых оледенений - окского, днепровского и московского - сказать ничего нельзя.

В период последнего - валдайского - оледенения льды наступали трижды, существенно меняя характер растительности, но не уничтожая ее полностью. При этом в лужскую стадию ледник покрывал почти всю территорию города, за исключением его юго-восточной окраины, где приледниковая флора сохранилась на Ижорском плато как наиболее приподнятой части территории. Во время межледниковий территория Петербурга покрывалась почти целиком то пресноводными, то морскими бассейнами. Правда, достаточно большая площадь все же возвышалась над уровнем водоемов, образуя острова или «материковую часть» (к югу от нынешнего города). В серии скважин от станции Пискаревка до бывшего совхоза Бугры был вскрыт один из торфяников, характеризующий флору болот средневалдайского времени. В нем обнаружены остатки мхов, характерных для холодных и умеренных широт северного полушария; определены также остатки хвощей (Equisetum), березы (Betula), сосны обыкновенной (Pinus sylvestris), nушицы (Eriophorum), тростника обыкновенного (Phragmites communis). Абсолютный возраст торфов - 39-40 тыс. лет. Обязательно следует заметить, что в валдайское время наблюдалось широкое распространение на территории Северо-Запада России так называемого мамонтового фаунистического комплекса.
Во время микулинского межледниковья, наступившего вслед за валдайским оледенением, климат на Северо-Западе России в целом был теплее современного за счет более высоких температур зимы, и территория города была почти целиком покрыта «Мгинским морем», называемым иногда Пра-Балтикой. Оно было связано проливами как с Эемским морем Западной Европы, так и с Белым морем. В конце микулинского межледниковья Мгинское море сменилось лагуной. Как следствие, почти нацело исчезли морские планктонные формы тепловодных водорослей, свидетельствовавшие о связи Пра-Балтики с морем Западной Европы; об опреснении моря свидетельствуют остатки пресноводных диатомовых водорослей. В морских глинах в скважине у станции метро Рыбацкая были найдены листья морской травы Зостеры (Zostera, или Взморник - однодольное водное растение, часто встречающееся вдоль побережья Балтийского моря и в наше время).

Остатки растений, произраставших на территории города во времена существования Балтийского ледникового озера, известны во многих местах. Развитие достаточно холодостойкой флоры суши и водоемов объясняется сохранением льдов на дне Балтийской впадины. По характерному растению Дриаде восьмилепестной (Dryas octopetala, или куропаточная травa, рис. 30), свойственной современным арктическим тундрам, три важных этапа в развитии флоры того времени были названы ранним, средним и поздним дриасом.

Наземная флора раннего дриаса носила перигляциальный (приледниковый) характер, что свидетельствует о значительно более суровом, чем в наше время, климате территории. Здесь в услови- 


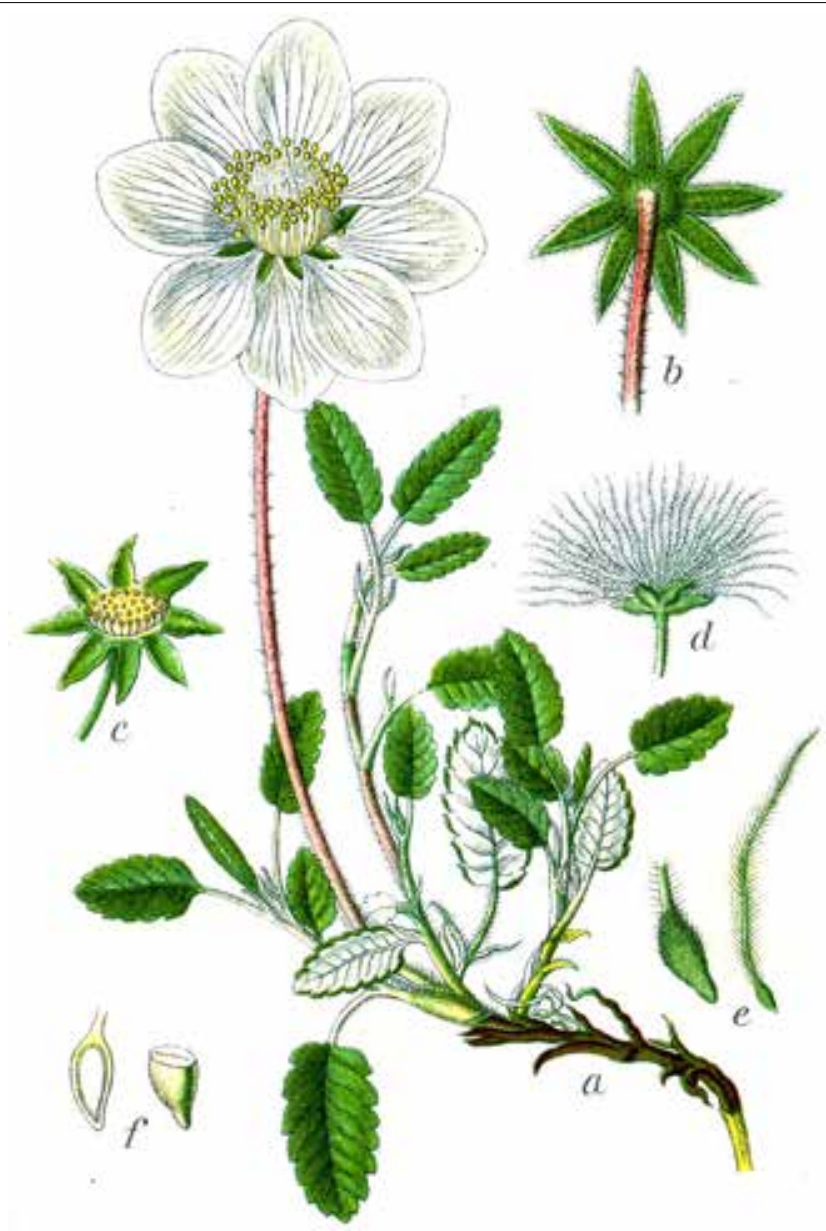

Рис. 30. Дриада восьмилепестная (Dryas octopetala). Ботаническая иллюстрация Якоба Штурма из книги «Deutschlands Flora in Abbildungen», 1796

ях арктического и субарктического климата широко развивались болота с карликовой березой (Betula nапа), полярными ивами (виды рода Salix) и дриадой восьмилепестной. В скважине в районе Лигово были обнаружены погребенные торфяники того времени, которые в основании состоят из гипнового торфа с осоками, а в верхней части содержат карликовую березу, дриаду, камылии и рдесть (Potamogeton). Интересно, что карликовая береза, типичный представитель арктической и субарктической тундры, до сих пор встречается в черте города, например, на болоте в парке Сосновки. Для раннего дриаса впервые отмечаются достоверные находки лишайников.

Следующий этап в развитии флоры, именуемый средним дриасом, наступил после регрессии морского бассейна в период времени, известный под названием бёллинг. Этот бассейн покрывал почти всю территорию города, доходя до Ижорского плато и тем самым уничтожив растительный покров суши, сформировавшийся в раннем дриасе. Среднедриасовые флоры в основном приурочены к подножью северного склона Ижорского плато и других возвышенностей, которые были берегами Первого Балтийского ледникового озера. Ледник окончательно отступил с южного побережья Балтийской впадины и нынешней Приневской низменности. Интересно, что флора, типичная для среднего дриаса, была впервые найдена в 30-X гг. XVIII в. при прокладке каналов на территории Александро-Невской лавры: в толще торфа, погребенного под современными осадками, наряду с карликовой березой и стелющимися формами ивы, багульником (Ledum palustre) и росянкой (Drosera), были обнаружены побеги дриады восьмилепестной. В озерно-ледниковых отложениях в Юкках, Осиновой роще и других местах города и пригородов встречены комплексы пыльцы и спор растений, типичных для полярной флоры. Близ пос. Горелово у подножия Балтийско-Ладожского глинта обнажаются органогенные осадки с древесинами, возраст которых был определен в $12150 \pm 390$ лет.

Уступы так называемой второй террасы Первого Балтийского ледникового озера хорошо прослеживаются на юго-западе Петербурга, в районе разветвления Петергофского и Таллинского шоссе (в районе Ульянки). Третья терраса, уступ которой имеет относительную высоту 10-12 м, тянется через все дворцово-парковые ансамбли от Стрельны до Петергофа и отделяет верхние парки, среди которых расположены дворцы Стрельны, Петродворца и Ломоносова, от нижних парков, находящихся на поверхности литориновой террасы. Непосредственно на абразионном уступе расположен главный каскад Петергофских фонтанов [15].

Значительное изменение растительного мира имело место около 11,5 тыс. лет назад в связи с морской трансгрессией, которая привела в течение периода времени, называемого аллерёд, к проникновению соленых вод Атлантики в Балтийскую впадину и образованию первого Иольдиевого моря (оно названо так по двустворчатому моллюску Ioldia arctica - Иольдия арктическая, широко распространенному в водах этого морского бассейна). Климат потеплел и стал близок к современному. Ель (Picea) и сосна (Pinus) доминировали в первом ярусе широко развитых лесных сообществ с участием дуба (Quercus), граба (Carpi$n u s)$ и других растений - пришельцев из флоры полесья и лесостепи, которые сохранились в наше время только на южном берегу Финского залива. Продолжалось широкое развитие болот с торфяными залежами и флорой, близкой к современной, а также усилилось заселение территории лишайниками.

Богатые комплексы пыльцы древесных растений с большой долей пыльцы орешника обнаружены в Охтинской низине и по южному побережью Финского залива в озерно-болотных отложениях Второго Балтийского ледникового озера следующей эпохи позднего дриаса. Наступившее похолодание было обусловлено положением края ледника - он продвинулся до южной Финляндии. Поздний дриас - завершающий этап в развитии флоры плейстоцена на территории Петербурга. Растительность этого времени вновь носит арктические черты.

К началу голоцена на Земле сложилась близкая к современной климатическая и ландшафтная зональность. С окончательным отступлением ледника с территории Салпаусселькя ${ }^{4}$ установился относительно сухой и холодный климат, определивший и характер флоры. Отдельные скопления льдов сохранялись лишь в Скандинавии и задерживались на дне Финской и Ладожской впадин. Последний факт явился причиной развития здесь флоры субарктического характера. Благодаря таянию льдов северного (и частично южного?) полушария уровень Миро-

\footnotetext{
${ }^{4}$ Салпаусселькя - возвышенность на юге и юго-востоке Финляндии и в Карелии. Представляет собой цепи гряд и холмов с абсолютными отметками до $250 \mathrm{M}$.
} 
вого океана повысился, и морские воды проникли в Балтийскую впадину, образовав Второе Иольдиевое море, уровень и соленость которого постоянно менялись, что нашло свое отражение в различном видовом составе диатомовых водорослей.

Поначалу на территории Петербурга и его ближайших окрестностей преобладала тундровая и лесотундровая растительность. В обнажениях, вскрытых в оврагах в парке Лесотехнической Академии на глубине около 1,5 м в торфе вместе с карликовой березой встречены дриада восьмилепестная, ива и горец (Polygonum); при бурении в районе станции метро Владимирская найдены семена лютика (Ranunculus) и нескольких видов рдестов.

В результате регрессии Второго Иольдиевого моря сформировалось замкнутое пресноводное Анциловое озеро (названное так по родовому названию моллюска Ancylus fluviatilis). По берегам озера появились сосново-березовые леса с подлеском из лещиhbl (Corylus). В скважине близ Морского торгового порта в илах обнаружены остатки сфагнума (Sphagпит), хвоша, осок (Сагех), мыттника болотного (Реdicularis palustris). На Лахтинском болоте в верхней части анциловой толщи встречены пыльца сосны и семена наяды гибкой (Najas flexilis), известной в озерах Ленинградской области и теперь ${ }^{5}$. По мере отмирания Анцилового озера сосновые леса, росшие на песчаных его берегах, постепенно уступали свое место березам и широколиственным породам деревьев. В конце анцилового времени на суше, освобожденной от вод озера, развивались торфяные болота, которые затем были погребены под толщей литориновых песков. Торф в верхней части залежей активно разлагался, что привело к формированию илистого осадка, известного под названием гиттии. На площади, оставленной ледниками, развивались также эоловые процессы, которые привели к формированию материковых дюн, выраженных в настоящее время в виде валообразных песчаных массивов, например, в районе Лахты.

Особенность развития растительного покрова суши в период существования следующего бассейна - Литоринового моря (названо так по моллюску Littorina littorea - Литорина прибрежная) - заключается прежде всего в максимальном распространении широколиственных пород: липь (Tilia), дуба, вяза (Ulmus), ясеня (Fraxinus), жимолости (Lonicera), лещцины (в скважине на Свердловской набережной близ устья реки Охты). В низинах произрастали черноольшаники, сохранившиеся до наших дней в некоторых местах по берегам Финского залива. В скважинах, пробуренных в черте города, встречены также остатки сальвинии плавающей (Salvinia natans), плоды водяного ореха (Trapa natans, или чилима) и наяды морской (Najas marina). Эти южные растения продвинулись тогда далеко к северу по берегам Литоринового моря. Абсолютный возраст торфа начала литоринового времени на территории Кронштадта определен в $6060 \pm 170$ лет. В разрезе Лахтинского болота высокое содержание пыльцы широколиственных пород сменяется кверху повышенным содержанием пыльцы ели. Затем в связи с

Детальные исследования Л.В. Филимоновой [26] в районе Сестрорецкого болота позволили восстановить растительные сообщества этого региона, сменявшие друг друга в течение голоцена, состоявшие более чем из ста видов растений. образованием песчаной пересыпи, отгородившей Лахтинский залив от моря, и опреснением водоема болото стало зарастать, переходя от грунтового к атмосферному питанию. Сначала появился осоковый, а потом сфагновый торф - они образуют современную поверхность торфяника. Во многих других болотах, сформировавшихся в то время, например, Шуваловском, наблюдается так называемый пограничный горизонт, абсолютный возраст которого определяют в 3500-4000 лет. В нем наблюдается сильно уплотненный торф со стволами сосен - следствие осушения территории в результате регрессии. На дне ушедшего Литоринового моря теперь располагается большая часть нашего города, а также в значительной мере заболоченная приморская низменная равнина, узкой полосой окаймляющая Финский залив и покрытая травяными и кустарниковыми сообществами.

Древние террасы - берега Литоринового моря высотой 6-7 метров можно видеть в виде уступов к северо-западу от Лахты вдоль Приморского шоссе вплоть до Сестрорецка, а также в районе ж/д станций Ланская и Удельная - уступ отчетливо выражен в парке Лесотехнической академии, поперек Большого Сампсониевского проспекта и в Удельнинском парке. Эти же террасы, но находящиеся ниже современного уровня Балтийского моря, разбурены скважинами на Васильевском острове и в районе Смольного на Новгородской улице. Скорее всего, именно абразионный уступ Литоринового моря-озера можно еще и сегодня наблюдать в центре Санкт-Петербурга, в проходных дворах между улицей Гагаринской и Соляным переулком, рядом с Мухинским училищем. Эта терраса сохранилась только во дворах старых зданий, а на окружающих улицах она давно уже выровнена и от нее не осталось и следа.

С периодом регрессии Литоринового моря связывают первые свидетельства появления древнего человека на нынешней территории Петербурга. Самая ранняя мезолитическая стоянка найдена в районе Тарховки на берегу Сестрорецкого Разлива, расположенная некогда на одной из террас Литоринового моря. Культурный слой с остатками кремневых орудий и отщепами оказался засыпанным дюнными песками. Предполагается, что эти первые пришельцы были охотниками и рыболовами. В 2008-2010 гг. в устье реки Охты, где планировалось возведение 400-метрового небоскреба - офисно-делового центра «Охта», были проведены охранные раскопки, позволившие восстановить историю заселения «Охтинского мыса» от неолита до настоящего времени. По данным петербургских геологов [29], в низах разреза встречаются вертикально забитые колья. Радиоуглеродная датировка их составляет $4690 \pm 80$ лет назад, то есть не исключено, что это - одно из самых древних свидетельств пребывания человека на территории нынешнего Санкт-Петербурга. Основными лесообразующими растениями в это время были сосна (Pinus sylvestris) и ель (Picea abies) при участии древовидных видов берез (Betula sect. Albae) и ольхи $($ Alnus). Реже встречались карликовая береза (Betula nana) и широколиственные породы - дуб (Quercus), вяз (Ulmus), липа (Tilia cordata), граб (Carpinus) и лещина (Corylus). Среди травянистых растений доминировали злаковые (Роасеае) при участии осок (Cурегасеае), вересковых (Ericaceae) и разнотравья Asteraceae, Rosaceae, Ranunculaceae и др. Из высших 


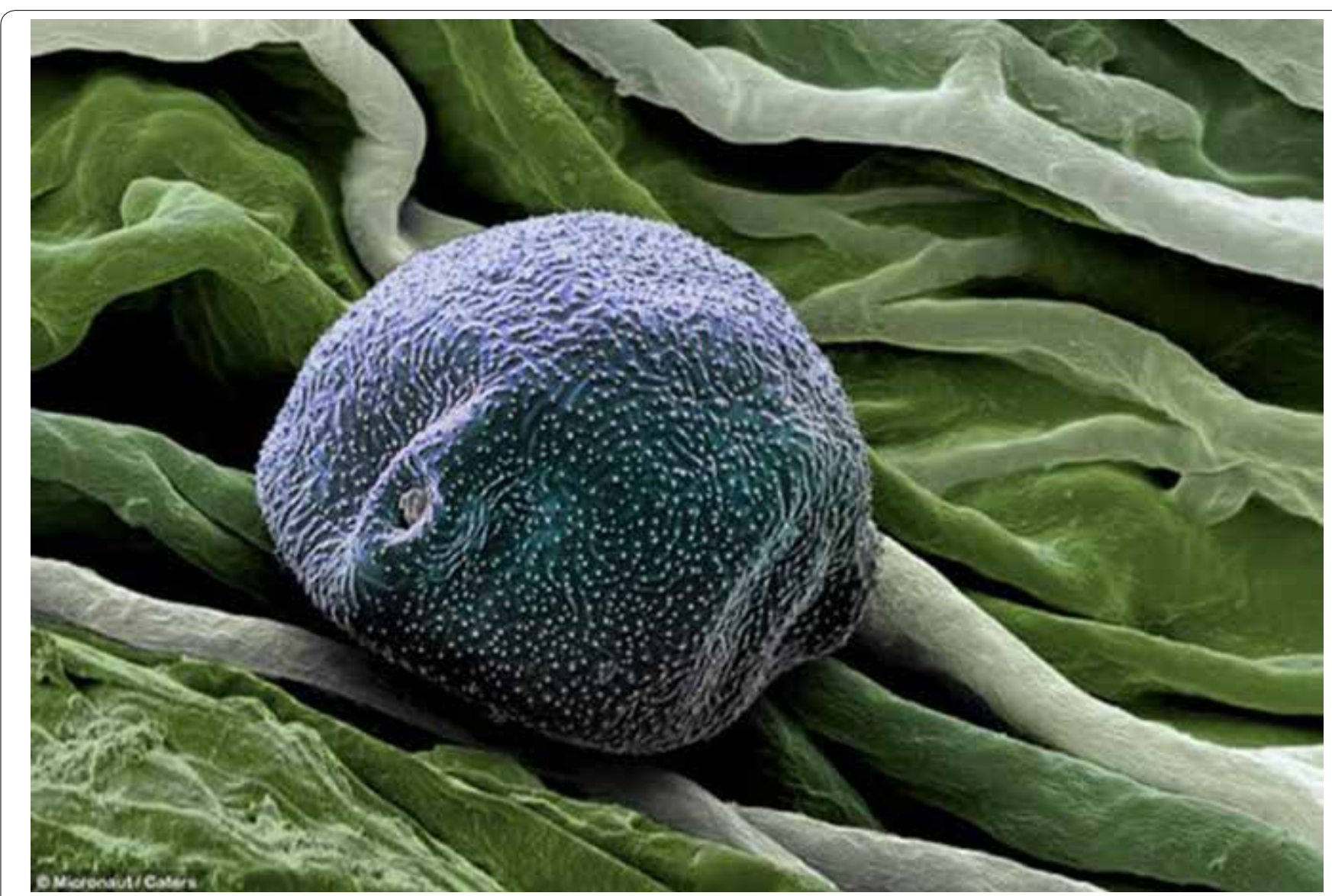

Рис. 31. Пыльца березы (Betula). Сильно увеличено. (http://kalyaev.com/2010/20100421/pollen.html)

споровых растений отмечаются папоротники (Polypodiaceae), сфагновые (Sphagnum) и другие мхи (Bryales), а также редкие плауны (Licopodium clavatum) [29]. Охтинский мыс был заселен в течение от начала неолита до настоящего времени, но наиболее широко известен благодаря существованию на нем двух шведских крепостей - Ландскроны (1300-1301 гг.) и Ниеншанца (1611-1703 гг.).

В конце неолита - начале бронзового века основной фон растительности, судя по ископаемой пыльце, составляли смешанные широколиственные леса с участием ели и cocнbl, а также чистые сосновые и еловые леса и дубравы, которые произрастали на моренных отложениях. Усилившуюся затем деградацию широколиственных лесов связывают с наступившим похолоданием, а также с антропогенным воздействием.

Целый ряд неолитических стоянок обнаружен в районе Сестрорецкого разлива, в Лахте, а также в Токсово на берегу Кавголовского озера. Все эти стоянки раньше были приурочены к берегам водоемов, а со временем оказались отрезанными от них в связи с обмелением водоемов и сейчас очень трудно распознаются среди лесных зарослей. Основными занятиями населения продолжали оставаться охота, рыболовство и оленеводство. При этом, судя по находкам в Приладожье, рыболовные сети плели из лыка и стеблей крапивы (Urtica), а поплавки делали, как иногда и в наше время, из коры cochbl. Многочисленные водные бассейны были для человека не только источником пищи, но наиболее удобными путями для передвижения в условиях лесной зоны. Так, в приладожских стоянках найдены остатки челна, сделанного из дуба. Возраст дерева, использовавшегося для постройки челна, был не менее 250 лет. Большое место занимало собирательство, в первую очередь ягод - малины (Rubus idaeus), ежевики (Rubus caesius) и др., а также водяного и лесного орехов, корневищ некоторых водных растений.

За последние 3500 лет растительность формировалась в основном под влиянием новой гидрографической сети, основной водной артерией которой являлась теперь Нева. Географическое положение территории на стыке океанического климата Западной Европы и континентальной Русской равнины определило разнородность состава флоры, сформировавшейся в результате соединения самых различных по происхождению и географическому распространению видов.

С применением палинологического и карпологического методов (изучения спор, пыльцы и семян различных растений, рис. 31) в последние годы установлена последовательность смен уровней Ладожского озера и связанных с этим миграций человека, вплоть до XVI в. [27, 28].

В настоящее время площади, занятые коренной растительностью, резко сокращаются. Вырубки, строительство, мелиорационные мероприятия, а также занос чужеземных растений на территории нынешнего Северо-Запада России существенно возросли с появлением здесь крупного города Санкт-Петербурга в 1703 г. 


\section{Литература}

\section{Список русскоязычной литературы}

1. Бурзин МБ. Эволюция бентосной растительности в позднем докембрии. Палеонт журнал. 2001;(5):78-86.

2. Гиршгорн ЛШ, Жамойда АИ, Ковалевский ОП и др. Стратиграфический кодекс России. 3-е изд. СПб.: ФГУП «ВСЕГЕИ»; 2006.

3. Гниловская МБ. Древнейшие водные растения венда Русской платформы (поздний докембрий). Палеонт журнал. 1971;(3):101-7.

4. Гниловская МБ. О древнейшей тканевой дифференциации докембрийских (вендских) водорослей. Палеонт журнал. 2003;(2):92-8.

5. Гниловская МБ, Ищенко АА, Колесников ЧМ и др. Вендотениды Восточно-Европейской платформы. Л.: Наука; 1988.

6. Горденко НВ, Орлова ОА, Снигиревский CM. Novgorodendron conophorum gen. et sp. nov. - новое плауновидное из нижнекаменноугольных отложений Московской синеклизы Палеонт журнал. 2006;(2):96-103.

7. Залесский МД. Растительные остатки из нижнекаменноугольных отложений бассейна p. Мсты. Записки Императ Минералогич Обва. 1905;XLII(2):313-42.

8. Залесский МД. О морском сапропелите силурийского возраста, образованном сине-зеленой водорослью. Изв Императ Академии Наук. 1917;(1):1-18.

9. Карпинский АП. О трохилисках. Тр. Геол Комитета, Нов сер. 1906;27:1-166. (То же: Собрание сочинений в 4 т. 1945; М.;Т 1:345-426.)

10. Мосейчик ЮВ. Раннекаменноугольная флора Подмосковного бассейна. Т. І. Состав, экология, эволюция, фитогеографические связи и стратиграфическое значение. М.: ГЕОС; 2009.

11. Мосейчик ЮВ. Раннекаменноугольная флора Подмосковного бассейна. Т. II. Членистостебельные, папоротники, голосеменные. М.: ГЕОC; 2014.

12. Наугольных СВ. Первые почвы и происхождение наземных растений. Наука в России. 2008;(1):37-43.

13. Орлова ОА, Снигиревский СМ. Поздневизейские лигиноптеридофиты (Lyginopteridophyta) из окрестностей г. Боровичи (Новгородская область). Часть 1. Каламопитиевые. Палеонт журнал. 2003;(6):105-11.

14. Орлова ОА, Снигиревский СМ. Поздневизейские лигиноптеридофиты (Lyginopteridophyta) из окрестностей г. Боровичи (Новгородская область). Часть 2. Лигиноптеридиевые и медуллозовые. Палеонт журнал. 2004;(4):104-9.

15. Путеводитель экскурсий А-15, C-15: Ленинград и Ленинградская область. IX конгресс Международного союза по изучению четвертичного периода. М.; 1982.

16. Словарь ботанических терминов. Под общ ред ИА Дудки. К.: Наукова думка; 1984.

17. Снигиревская НС. Поздний девон - время появления лесов как природного явления.
В: Становление и эволюция континентальных биот. Tp. XXXI сессии Всесоюзного Палеонт Об-ва. Л.: ВСЕГЕИ; 1988:115-24.

18. Снигиревская НС. Археоптерисовые и их значение в эволюции растительного покрова суши. Бот журнал. 1995; 80(1):70-6.

19. Снигиревская НС. Новые отделы Archaeopteridophyta и Archaeospermatophyta и их отношения с некоторыми другими группами девонских растений. Бот журнал. 2000;85(7):134-44.

20. Снигиревская НС, Снигиревский СМ. Местонахождение тропической флоры раннего карбона на реке Мсте - порог Витца. В: Исследования природного и историко-культурного комплексов Национального парка «Валдайский». Материалы к региональной научно-практической конференции, посвященной 15-летию Национального парка «Валдайский». Валдай; 2005:152-4.

21. Снигиревский СМ. Древнейшие лесообразующие растения Земли и проблема критического пересмотра состава рода $A r$ chaeopteris. Топорковские чтения. Рудный; 1999;IV:454-8.

22. Снигиревский СМ, Орлова ОА. Некоторые новые находки плауновидных и членистостебельных растений в визейских отложениях северо-западного крыла Московской синеклизы. В: Палеоботаника на рубеже веков: итоги и перспективы. Тез IV чтений памяти АН Криштофовича. СПб;2001:38-40.

23. Снигиревский СМ, Снигиревская НС. Ископаемые растения в окрестностях СанктПетербурга. В: Снигиревский СМ, Синай МЮ, ред. Многогранная геология. СПб: ВНИИОкеангеология; 2008. Вып 2: с. 121-39.

24. Тимофеев БВ. Древнейшая флора Прибалтики и ее стратиграфическое значение. Тр ВНИГРИ;1959;129. Л.: Гостоптехиздат:1-320.

25. Федоров ПВ. Раннеордовикские органогенные постройки северо-запада России. III. Геккеровы горбы долины р. Тосна. Вестн СПбГУ Сер 7. Геол геогр. 2000;2(15):84-91.

26. Филимонова ЛВ. Динамика растительности восточного побережья Финского залива в голоцене. Тр Карельского НЦ РАН. Петрозаводск. 2009;(4):11-29.

27. Шитов МВ, Кильдюшевский ВИ, Плешивцева ЭС, Сумарева ИВ. Городская среда, землепользование и сельское хозяйство в средневековой Ладоге и ее округе (по палинологическим данным). I. Конец IX-XVI вв. Вестн СПбГУ Сер 7. Геол геогр. 2007a;(1):40-50.

28. Шитов МВ, Константинова ТА, Лоскутов ИГ и др. Городская среда, землепользование и сельское хозяйство в средневековой Ладоге и ее округе (по палинологическим и карпологическим данным). II. Середина I тыс. от Р. X. середина IX в. Вестн СПбГУ Сер. 7. Геол геогр. 20076;(3):35-50.

29. Шитов МВ, Арсланов ХА, Бискэ ЮС и др. Голоценовая толща Охтинского мыса: страти- 
графия и условия формирования. Бюллетень ИИМК РАН. 2010;(1):178-91.

30. Эйхвальд ЭИ. Палеонтология России. Древний период. І. Флора граувакковой, горноизвестковой и медистосланцеватой формаций России. СПб.; 1854.

31. Янишевский МЭ. Кембрийские отложения Ленинградской области. Учен Зап ЛГУ. Сер географ наук. Вып. 1: Труды Саблинской научно-учебной станции ЛГУ. 1939;(25):1-31.

\section{Общий список литературы/Reference List}

1. Burzin MB. [Evolution of benthic vegetation in the late Precambrian]. Paleontologicheskiy Zhurnal. 2001;(5):78-86. (In Russ.)

2. Zhamoida AI, Girshgorn LCh, Kovalevsky $\mathrm{OP}$ et al. Stratigraficheskiy Kodeks Rossii 3-ye Izdaniye [Stratigraphic Code of Russia]. $3^{\text {rd }}$ ed. Saint Petersburg: VSEGEI; 2006. (In Russ.)

3. Gnilovskaja MB. [The earliest Vendian water plants of the Russian platform (Late Precambrian)]. Paleontologicheskiy Zhurnal. 1971;(3):101-7. (In Russ.)

4. Gnilovskaya MB. [The earliest tissue differentiation in Precambrian (Vendian) algae]. Paleontologicheskiy Zhurnal. 2003;(2):92-8. (In Russ.)

5. Gnilovskaya MB, Istchenko AA, Kolesnikov $\mathrm{ChM}$ et al. Ventoteneidy Vostochno-Yevropeiskoy Platformy. [Vendotaenids of the East European Platform]. Leningrad: Nauka; 1988. (In Russ.)

6. Gordenko NV, Orlova OA, Snigirevsky SM. [A New Lycopod, Novgorodendron conophorum gen. et sp. nov., from the Lower Carboniferous of the Moscow Syneclise]. Paleontologicheskiy Zhurnal. 2006;(2):96-103. (In Russ.)

7. Zalessky MD. [Plant fossils from the Lower Carboniferous strata of River Msta basin]. Zapiski Imperatorskogo Mineralogicheskogo Obshtchestva. 1905;XLII(2):313-42. (In Russ.)

8. Zalessky MD. [On sapropelite of the Silurian sea formed by blue-green algae]. Izvestia Imperatorskoj Akademii Nauk. 1917;(1):1-18. (In Russ.)

9. Karpinsky AP. [On the Trochilisks]. Trudy Geologiczeskogo Komiteta. Novaya Seriya. 1906;27:1166. (See also: Sobraniye Sochineniy [Collected works]. Moscow; 1945. Vol. 1, p. 345-426.)

10. Mosseichik JuV. Rannekamennougolnaya Flora Podmoskovnogo Basseyna. T. I. Sostav, Ekologiya, Evoliutsiya, Fitogeografficheskiye Sviazi i Stratigraficheskoye Znacheniye [Early Carboniferous flora of Moscow Coal Basin. Volume I. Composition, Ecology, Evolution, Phytogeographic relations, and Stratigraphic Significance]. Moscow: GEOS; 2009. (In Russ.)

11. Mosseichik JuV. Rannekamennougolnaya Flora Podmoskovnogo Basseyna. T. II. Tchlenistostebel'nye, Paporotniki, Golosemennye. [Early Carboniferous flora of Moscow Coal Basin. Volume II. Equisetophyta, Ferns, and Gymnospermae]. Moscow: GEOS; 2014. (In Russ.)

12. Naugolnykh SV. [The first soils and the origin of land plants]. Nauka v Rossiji. 2008;(1):3743. (In Russ.)

13. Orlova OA, Snigirevsky SM. [Late Visean Lyginopteridophytes from the vicinity of the town of Borovichi (Novgorod Region). 1. Cal- amopityales]. Paleontologicheskiy Zhurnal. 2003;(6):105-11. (In Russ.)

14. Orlova OA, Snigirevsky SM. [Late Visean Lyginopteridophytes from the vicinity of the town of Borovichi (Novgorod Region). 2. Lyginopteridales and Medullosales]. Paleontologicheskiy Zhurnal. 2004;(4):104-9. (In Russ.)

15. Putevoditel Ekskursiy A-4, S-15: Leningrad i Leningradskaya Oblast. IX Kongress Mezhdunarodnogo Soyuza po Izucheniyu Chetvertichnogo Perioda [Leningrad Excursions Guidebook A-15, C-15: Leningrad and Leningrad region. IX Congress of International Union for Quaternary Research]. Moscow; 1982.

16. Dudka IA, ed. Slovar' Botanicheskikh Terminov. [Dictionary of Botanical Terms]. Kiev: Naukova Dumka; 1984. (In Russ.)

17. Snigirevskaya NS. Late Devonian: the time of the appearance of forests as a natural phenomenon. In: Stanovlenije i Evolutsiya Kontinental'nykh Biot. Trudy XXXI Sessii Vsesojuznogo Paleontologicheskogo Obshtchestva. Leningrad: VSEGEI; 1988. p. 115-24. (In Russ.)

18. Snigirevskaya NS. [Archaeopterids and their role in the evolution of terrestrial vegetation]. Botanicheskiy Zhurnal. 1995;80(1):70-6. (In Russ.)

19. Snigirevskaya NS. [Archaeopteridophyta and Archaeospermatophyta divisio novum and their relations with some other groups of Devonian plants]. Botanicheskiy Zhurnal. 2000;85(7):13444. (In Russ.)

20. Snigirevskaya NS, Snigirevsky SM. [Locality of tropical Early Carboniferous flora at Vittsa rapids of the river Msta]. In: Issledovanija Prirodnogo i Istoriko-Kulturnogo Kompleksov Natsional'nogo Parka "Valdayskiy". Materialy k Regional'noy Nauchno-Prakticheskoy Konferentsii, Posviashchennoy 15-letiyu Natsional'nogo Parka "Valdayskiy". Valday; 2005:152-4. (In Russ.)

21. Snigirevsky SM. [The earliest forest forming plants of the Earth and the problem of the critical review of the genus Archaeopteris]. In: Toporkovkye Chteniya. Rudnyi; 1999. Vol. IV, p. 454-8. (In Russ.)

22. Snigirevsky SM, Orlova OA. [Some novel findings of lycopsid and equisetalean plants in the Visean sediments of the north-west wing of the Moscow syneclise]. In: Paleobotanika na Rubezhe Vekov: Itogi i Perspektivy. Tezisy IV Chteniy Pamiati AN Krishtofovicha. Saint Petersburg; 2001. p. 38-40.

23. Snigirevsky SM, Snigirevskaya NS. [Fossil plants in the vicinity of Saint Petersburg]. In: Snigirevsky SM, Sinaj MYu, eds. Mnogogrannaya Geologiya. Saint Petersburg: VNIIOkeangeologija; 2008. Issue 2, p. 121-39.

24. Timofeyev BV. [The earliest flora of Baltic region and its stratigraphic significance]. Trudy VNIGRI;1959:1-320. (In Russ.)

25. Fedorov PV. [Early Ordovician bioherms of the North-West of Russia. III. Hecker humps of the river Tosna valley]. Vestnik Sankt-Peterburgskogo Gosudarstvennogo Universiteta Seriya 7 Geologiya Geografiya. 2000;2(15):84-91. (In Russ.)

26. Filimonova LV. Vegetation dynamics on the eastern coast of the gulf of Finland in the Holocene. 
Trudy Karel'skogo Nauchnogo Tsentra Rossiyskoy Akademii Nauk. 2009;(4):11-29. (In Russ.)

27. Sheetove MV, Kildushevskyi VI, Pleshivtseva ES, Sumareva IV. [Environment, land use history and agriculture at medieval Staraya Ladoga and its vicinity (by pollen data). 1. Late X-XVI centuries]. Vestnik Sankt-Peterburgskogo Gosudarstvennogo Universiteta Seriya 7 Geologiya Geografiya. 2007;(1):40-50.

28. Sheetov MV, Konstantinova TA, Loskutov IG et al. [Environment, land use history and agriculture at medieval Staraya Ladoga and its vicinity (by palynological and carpological data). II. Mid- I millennium - the middle of the IX century]. Vestnik Sankt-Peterburgskogo Gosudarstvennogo Universiteta Serija 7 Geologija, Geografija. 2007;(3):35-50.

29. Shitov MV, Arslanov KhA, Biskè YuS et al. [Holocene rock strata of the Okhta Promontory: stratigraphy and the conditions of their formation]. Biulleten' Instituta Material'noy Kultury Rossiyskoy Akademii Nauk. 2010;(1):178-91.

30. Eichwald EI. Paleontologiya Rossii. Drevniy Period. I. Flora Grauvakkovoy, Gornoizveskovoy i Medistoslantsevatoy Formaytsiy Rossi. [Palaeontology of Russia. Ancient Period. I. Flora of Grauwak- ke, Bergkalk and Kupferschiefer Formations]. Saint Petersbourg; 1854. (In Russ.)

31. Yanishevsky M. [The Cambrian of Leningrad region]. Uchenye Zapiski LGU Seriya Geograficheskikh Nauk 1939;(25):1-31.

32. Hueber FM. Rotted wood-alga-fungus: the history and life of Prototaxites Dawson, 1859. Rev Palaeobot Palynol. 2001;116(1/2):123-58.

33. Orlova OA, Mamontov DA, Snigirevsky SM. Late Visean (Mississippian) vegetation of the north-western part of Russia according to palaeobotanical and palynological data. Historical Biology. 2015;27(3-4):325-44.

34. Scotese CR, McKerrow WS. Revised world maps and introduction. Mem Geol Soc London. 1990;12:1-21

35. Snigirevskaya NS, Snigirevsky SM. New locality of Callixylon (Archaeopteridaceae) in the Upper Devonian of Andoma mountain (Vologda district, North-West of Russia) and its importance for the reconstruction of Archaeopterids distribution. Acta Palaeobotanica. 2001;41(2):97-105.

36. Zalessky MD. Über einen neuen Vertreter der Gattung Archaeopteris Dawson von dem Fluß Mda, einem Nebenfluß des Msta aus den nordwestlichen Flanke des Moskauer Steinkohlenbeckens. Neues Jahrb Mineral, Geol, Paläontol. Abt B. 1944;(7-9):185-8. 